OPEN ACCESS

Edited by:

Jason Sahl,

Northern Arizona University, United States

Reviewed by:

Remy A. Bonnin,

Université Paris-Saclay, France Laura Villa,

National Institute of Health (ISS), Italy

*Correspondence.

Marcelo E. Tolmasky mtolmasky@fullerton.edu

Specialty section:

This article was submitted to

Antimicrobials, Resistance

and Chemotherapy,

a section of the journal

Frontiers in Microbiology

Received: 20 March 2019

Accepted: 05 September 2019

Published: 20 September 2019

Citation:

Ramirez MS, Iriarte A

Reyes-Lamothe R, Sherratt DJ and Tolmasky ME (2019) Small Klebsiella pneumoniae Plasmids: Neglected

Contributors to Antibiotic Resistance.

Front. Microbiol. 10:2182.

doi: 10.3389/fmicb.2019.02182

\section{Small Klebsiella pneumoniae Plasmids: Neglected Contributors to Antibiotic Resistance}

\author{
Maria S. Ramirez ${ }^{1}$, Andrés Iriarte², Rodrigo Reyes-Lamothe ${ }^{3}$, David J. Sherratt ${ }^{4}$ and \\ Marcelo E. Tolmasky ${ }^{1,4 *}$ \\ ${ }^{1}$ Center for Applied Biotechnology Studies, Department of Biological Sciences, College of Natural Sciences \\ and Mathematics, California State University Fullerton, Fullerton, CA, United States, ${ }^{2}$ Laboratorio de Biología \\ Computacional, Departamento de Desarrollo Biotecnológico, Facultad de Medicina, Universidad de la República \\ de Uruguay, Montevideo, Uruguay, ${ }^{3}$ Department of Biology, Mc Gill University, Montreal, QC, Canada, ${ }^{4}$ Department \\ of Biochemistry, University of Oxford, Oxford, United Kingdom
}

Klebsiella pneumoniae is the causative agent of community- and, more commonly, hospital-acquired infections. Infections caused by this bacterium have recently become more dangerous due to the acquisition of multiresistance to antibiotics and the rise of hypervirulent variants. Plasmids usually carry genes coding for resistance to antibiotics or virulence factors, and the recent sequence of complete $K$. pneumoniae genomes showed that most strains harbor many of them. Unlike large plasmids, small, usually high copy number plasmids, did not attract much attention. However, these plasmids may include genes coding for specialized functions, such as antibiotic resistance, that can be expressed at high levels due to gene dosage effect. These genes may be part of mobile elements that not only facilitate their dissemination but also participate in plasmid evolution. Furthermore, high copy number plasmids may also play a role in evolution by allowing coexistence of mutated and non-mutated versions of a gene, which helps to circumvent the constraints imposed by trade-offs after certain genes mutate. Most $K$. pneumoniae plasmids $25-\mathrm{kb}$ or smaller replicate by the ColE1-type mechanism and many of them are mobilizable. The transposon Tn1331 and derivatives were found in a high percentage of these plasmids. Another transposon that was found in representatives of this group is the bla KPC-containing Tn4401. Common resistance determinants found in these plasmids were aac $\left(6^{\prime}\right)-1 b$ and genes coding for $\beta$-lactamases including carbapenemases.

Keywords: transposon, integron, plasmid, ESKAPE, Klebsiella, multidrug resistance

\section{INTRODUCTION}

Klebsiella pneumoniae, although usually carried by healthy humans, is also the causative agent of community- and, more commonly, hospital-acquired infections, accounting for more than $30 \%$ of those caused by Gram-negative bacteria (Kalpoe et al., 2012; Shon et al., 2013; Li et al., 2014; Calfee, 2017; Navon-Venezia et al., 2017). K. pneumoniae became more dangerous in recent years due to the acquisition of multidrug resistance (Almaghrabi et al., 2014; Chen et al., 2014a; Ramirez et al., 2016; Rojas et al., 2017b) and the emergence of hypervirulent variants 
(Decre et al., 2011; Kalpoe et al., 2012; Shon et al., 2013). The most common diseases in Western countries, caused by classic (non-hypervirulent) strains, are urinary tract infections, pneumonia, septicemias, meningitis, and soft tissue infections (Shon et al., 2013; Ramirez et al., 2016; Calfee, 2017; Martel et al., 2017; Gupta et al., 2018; Osman et al., 2018). K. pneumoniae may also play a role in ankylosing spondylitis and Crohn's disease (Rashid et al., 2013, 2016). Hypervirulent variants overproduce capsular polysaccharide and are hypermucoviscous, a phenotype defined when an inoculation loop or needle generates a viscous string $>5 \mathrm{~mm}$ in length by stretching bacterial colonies on an agar plate (Shon et al., 2013). They are characterized for showing metastatic spread and causing life-threatening communityacquired infections like liver abscess, pneumonia, osteomyelitis, meningitis as well as endophthalmitis in immunocompetent healthy individuals (Cheng et al., 1991; Chen et al., 2004, 2019; Sobirk et al., 2010; Decre et al., 2011; Shon et al., 2013; Prokesch et al., 2016; Martel et al., 2017; Zhan et al., 2017; Gupta et al., 2018; Jun, 2018; Osman et al., 2018; Yao et al., 2018; Marr and Russo, 2019).

As it is the case with most bacteria, virulence factors and drug resistance traits are commonly encoded by K. pneumoniae plasmids (Nassif and Sansonetti, 1986; Nassif et al., 1989a,b; Wacharotayankun et al., 1993; Deleo et al., 2014; Ramirez et al., 2014a; Navon-Venezia et al., 2017; Peirano et al., 2017; Rozwandowicz et al., 2018; Turton et al., 2018). The recent completion and analysis of genomes of numerous $K$. pneumoniae strains clarified different characteristics of their chromosomes and showed that they usually harbor several plasmids with a broad range of sizes from a few to several hundred $\mathrm{kb}$ (Nassif et al., 1989a; Liu et al., 2012; Ramirez et al., 2012, 2014b, 2016; Deleo et al., 2014; Martin and Bachman, 2018). The larger plasmids are usually low copy number and may include genes and functions like antibiotic resistance, virulence factors, and conjugation properties. This rich combination of genes involved in virulence and resistance to treatment, together with the ability to disseminate these traits, attracted the majority of the efforts to study the properties and biology of K. pneumoniae plasmids (Chen et al., 2004; Soler Bistue et al., 2008; GarciaFernandez et al., 2012; Mathers et al., 2015; Conlan et al., 2016; Rojas et al., 2017a,b; Zhou et al., 2017; Desmet et al., 2018). However, although carrying a more modest number of genes, small high-copy number plasmids are of interest because they have a significant impact on bacterial infection harboring a variety of resistance genes that are expressed at high levels and that are usually included in mobile elements. These plasmids also play important, albeit still understudied, roles in plasmid evolution through events mediated by mobile elements as well as several recombinational mechanisms of cointegration with other plasmids that can be followed by imprecise resolution (Zakharova et al., 2002; Bui et al., 2006; Tran et al., 2012; Lin et al., 2013; Ramirez et al., 2014a; He et al., 2015; Cameranesi et al., 2018). Recent studies also showed that multicopy plasmids promote evolution by permitting the coexistence of novel and ancestral traits when a new variant arises through mutation, allowing bacteria to escape the evolutionary constraints imposed by the trade-offs that otherwise would limit the perpetuation of certain gene changes (Rodriguez-Beltran et al., 2018). Furthermore, the usual higher copy number of small plasmids may facilitate the enhancement of resistance levels by gene dosage (Tolmasky et al., 1988; Sandegren and Andersson, 2009).

\section{THE pJHCMW1 PLASMID}

The most studied K. pneumoniae plasmids are those that code for the complete conjugation machine, virulence factors, and mobile elements (de Toro et al., 2014). They are usually larger than $30-\mathrm{kb}$ and can reach several hundred $\mathrm{kb}$. Smaller $K$. pneumoniae plasmids, $\sim 25$-kb or less, have attracted much less attention and the majority of the studies are limited to the analysis of their nucleotide sequences and a few complementary experiments. A notable exception is pJHCMW1, isolated from K. pneumoniae JHCK1, which caused several fatalities in a neonatal ward as a consequence of resistance to the antibiotic treatment (Tolmasky et al., 1986; Woloj et al., 1986; Xie et al., 2013). The pJHCMW1 plasmid includes the transposon Tn1331 (nucleotides 3362-11654) and a 3361-nucleotides region that contains the genetic traits specific to inheritance and conjugation (Figure 1A) (Dery et al., 1997; Sarno et al., 2002). A BLAST analysis of this region showed homology to several plasmids. However, the homology was mostly confined to the ColE1-type replication region (Figure 2A) (Pasquali et al., 2005; Tolmasky et al., 2010; Ye et al., 2010; Fricke et al., 2011; Sun et al., 2013; Brantl, 2014; Porres-Osante et al., 2014; Calva et al., 2015; Cao et al., 2015; Lilly and Camps, 2015; Liu et al., 2015). The pJHCMW1 plasmid includes a functional oriT but lacks the genes coding for the relaxosome and the transferosome (Dery et al., 1997) (Figure 1A). Since K. pneumoniae strains usually harbor numerous plasmids, pJHCMW1 may occasionally be transferred to other strains when one or more co-resident plasmids contribute the appropriate helper functions. This was confirmed in a mobilization assay using a recombinant clone, pROXT1, generated by inserting the pJHCMW1 oriT region into pUC4K, and pRK2073 (Leong et al., 1982), a plasmid that includes the whole RK2 conjugation machinery. In a triparental mating including a recipient E. coli and E. coli strains carrying pROXT1 or pRK2073, the transfer frequencies of both plasmids were of the same order $\left(1\right.$ and $3.3 \times 10^{-1}$, respectively) (Dery et al., 1997). This experiment showed that if the appropriate machinery is coded for by another resident plasmid, pJHCMW1 can be mobilized in trans at frequencies comparable to those of the self-transmissible helper plasmid. Until recently, it was considered unusual that mobilizable plasmids include an oriT but not the genes coding for the specific relaxosome components. However, recent work on conjugation and mobilization of staphylococcal plasmids showed that many, some of them smaller than $5-\mathrm{kb}$, are transferred by relaxase-in trans mobilization, as it is the case for pJHCMW1 (O'Brien et al., 2015). Further studies showed that a large percentage of $S$. aureus plasmids include oriT mimics indicating that the number of plasmids with mobilization capabilities may be much higher than initially thought (Ramsay et al., 2016). The pJHCMW1 plasmid also possesses a Xer site-specific 

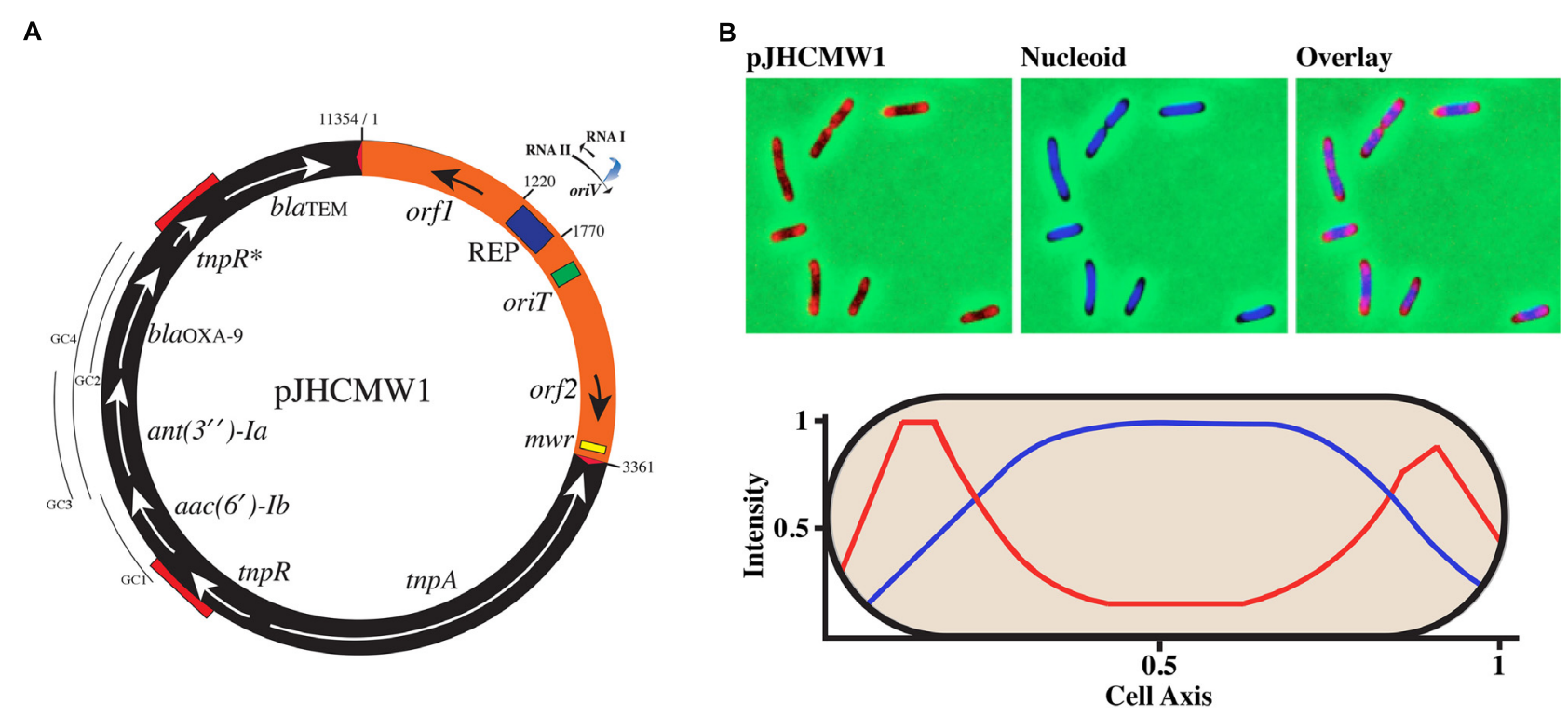

FIGURE 1 | Genetic map and subcellular localization of pJHCMW1. (A) The numbers indicate the coordinates as defined in GenBank (accession number AF479774). The region harboring the inheritance functions is shown in orange and boxes inside indicate the location of the replication region (REP) and oriT and $m w r$ loci. The RNA I and RNA II within the replication region are shown with their transcription orientation (arrowheads). The blue arrow represents the location of RNase $\mathrm{H}$ digestion where DNA polymerase I initiates replication (oriV). The black arrow adjacent to REP is a gene that codes for a PH domain-containing protein of unknown function. The black arrow adjacent to the mwr site represents a gene coding for a hypothetical protein of unknown function. The black region represents Tn1331. The red triangles represent the inverted repeats (GGGGTCTGACGCTCAGTGGAACGAAAACTCACGTTAAG) and the red segments on top of the circle indicate repeated sequences most probably formed during the genesis of the transposon. The segment including one of these repeated sequences plus the region between them is the addition to Tn3 that formed Tn1331 (Tolmasky, 2000). The lines labeled as GC1, GC2, GC3, and GC4 indicate the location of the gene cassettes. GC1 and GC2 are non-functional, GC3 is poorly functional, and GC4, which includes both ant(3")-la, and blaoxA-9, is fully functional (Ramirez et al., 2008). (B) The top panels show images of cells carrying the PJHCMW1 derivative pTT4 that possesses the TetO. The panel to the left shows the cells labeled using TetR-YPet to detect plasmid molecules, the center panel shows labeling with DAPI to detect the nucleoid, and the panel to the right shows an overlay of nucleoid and plasmid signals. The bottom panel shows the levels of fluorescent signals using the same colors as the top panels over a cell's length. The values are averages of measurements from 329 cells.

recombination site, $m w r$, which was thoroughly characterized (Figure 1A) (Tolmasky et al., 2000; Pham et al., 2002; Bui et al., 2006; Trigueros et al., 2009; Tran et al., 2010; Ramirez et al., 2014a). Xer site-specific recombination sites play roles in different processes like plasmid stability by promoting dimer resolution or plasmid evolution by formation and resolution of cointegrates and promoting integration of resistance genes and mobile elements (Zakharova et al., 2002; D'Andrea et al., 2009; Merino et al., 2010; Tran et al., 2012; Das et al., 2013; Midonet and Barre, 2014, 2016; Boyd et al., 2017; Cameranesi et al., 2018). They also participate in processes not involving plasmids such as chromosome dimer resolution or integration of IMEXs (integrative mobile elements exploiting Xer) (Barre et al., 2001; Sherratt et al., 2001; Midonet and Barre, 2014, 2016; Midonet et al., 2019).

While the partition systems required to ensure proper segregation of low copy number plasmids have been thoroughly studied in numerous systems (Baxter and Funnell, 2015), small high copy number plasmids received scarce attention because it was thought that random diffusion was sufficient to avoid generating plasmidless cells after cytokinesis. Few reports are available, and they all have in common that most plasmid molecules are located in the nucleoid-free regions. Localization of pJHCMW1, which has a calculated copy number of 24 when cells are about to divide, using fluorescence microscopy showed that while the bulk of the fluorescence was localized at the poles in nucleoid-free spaces, the shape and position of the fluorescent spots changed over time suggesting that the molecules were only partially restricted to the cell poles (Reyes-Lamothe et al., 2014). Furthermore, when the nucleoidfree spaces were increased using a mutant or treating wildtype cells with cephalexin, the fluorescence occupied all the space suggesting that most molecules are excluded from the chromosomal DNA mass in the nucleoid, pushing them to regions of low chromosomal density (Figure 1B) (ReyesLamothe et al., 2014). This process is similar to the exclusion suffered by ribosomes (Robinow and Kellenberger, 1994), whose diameter of gyration - a measure of the size of a polymer, numerically defined as the average of the squared distance of a point in a polymer from its center of mass - is significantly smaller $(18 \mathrm{~nm})$ than that of pJHCMW1 (265 nm) (Willumeit et al., 1997; Reyes-Lamothe et al., 2014). It was concluded that pJHCMW1 segregates by random diffusion but with most molecules occupying the nucleoid-free polar regions of the cell. Other studies found high copy number plasmids clustered at the cell poles or combining some molecules randomly distributed throughout the cell and some others clustered (Pogliano et al., 2001; Yao et al., 2007; Wang et al., 2016; Standley et al., 2019). 
A

pJHMW1

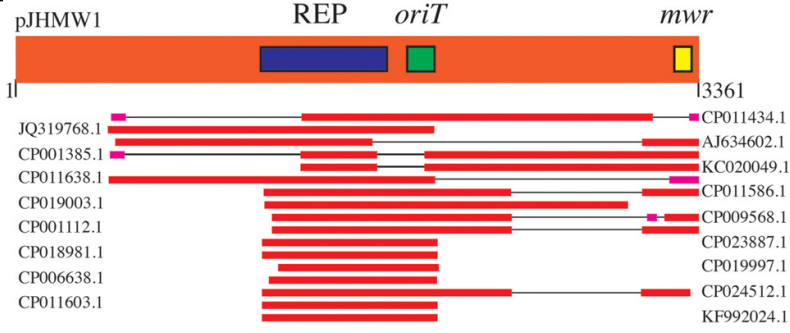

B

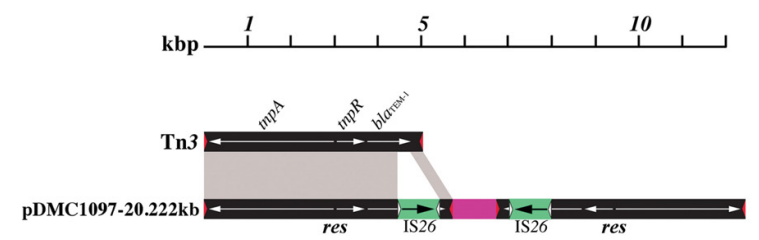

C

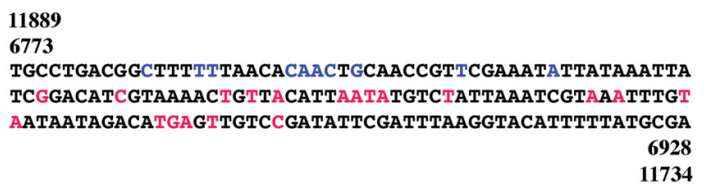

D

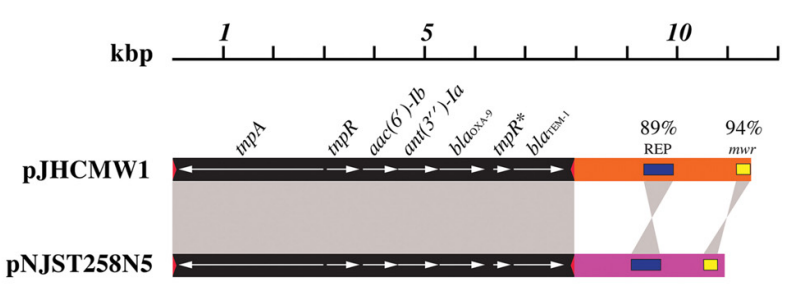

E

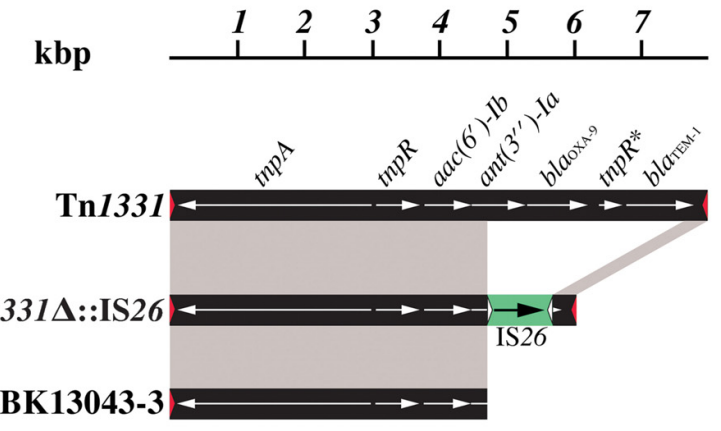

FIGURE 2 | Small K. pneumoniae plasmids and mobile elements. (A) The pJHCMW1 region containing the inheritance functions (3361 nucleotides) was analyzed using BLAST and the plasmids showing homology in segments larger than the REP region are shown in the figure. Homology analysis was done using BLAST (Ncbi_Resource_Coordinators, 2018). (B) Comparison of the genetic maps of Tn3 and the pDMC1097-20.222kb transposon-like structure. The nucleotide sequence of Tn3 (accession number V00613) was compared to that of pDMC1097-20.222kb (accession number NZ_CP011979.1). Two inverted repeated structures with homology to a region at the right end of Tn3 are present in pDMC1097-20.222kb. Black blocks show Tn3 or Tn3 sequences and the red triangles represent the Tn3 inverted repeats (GGGGTCTGACGCTCAGTGGAACGAAAACTCACGTTAAG). Gray shadows show homologous regions. The large region of homology has 4335/4400 identical nucleotides, most differences are located within tnpR. The small region shows 320/320 identical nucleotides. The gray shadows are shown only in one of the inverted repeated elements in pDMC1097-20.222kb. The green blocks represent the IS26 and the white triangles show the IS26 inverted repeats (GGCACTGTTGCAAA). The DNA segment between the mobile elements (red) includes three pseudo genes, two of them corresponding to a serine hydrolase and the other a hypothetical protein. (C) Nucleotide sequence of the res regions of the pDMC1097-20.222kb mobile elements diagrammed in (B). The numbers indicate the coordinates as shown in GenBank. The letters shown in color are the nucleotides that differ in Tn1, Tn2, and Tn3 as described before (Partridge and Hall, 2005). Black, identical in Tn1, Tn2, and Tn3. Blue, identical to those in Tn3. Red, identical to Tn2. (D) Comparison of the genetic maps of pJHCMW1 and pNJST258N5. The black bars represent Tn1331 and the orange and pink bars represent the DNA regions that include the inheritance functions. The coordinates of pJHCMW1 and pNJST258N5 have been modified from those in GenBank (accession numbers AF479774 and CP006924, respectively) to facilitate the comparison. Straight and crossed gray shadows represent direct and inverse orientation. The nucleotide sequences of the transposon share $99 \%$ identity. The numbers in the replication (REP) and Xer-recombination site ( $m w r)$ indicate the percent homology. (E) Comparison of the genetic maps of Tn1331 and Tn1331-like structures. Black blocks represent Tn1331 or Tn1331 sequences and the red triangles represent the Tn1331 inverted repeats, which are identical to those of Tn3. The IS26 sequence present in Tn1331 $\Delta$ :IS26 is shown as a green block. The white triangles show the inverted repeats. The accession numbers of the sequences used for this figure are AF479774 (Tn1331), JF828150 (Tn1331 A:IS26), and CP020840 (pBK13043-3).

Also, the possibility of active partition has been considered (Million-Weaver and Camps, 2014). However, it should be noted that some of these latter studies were carried out with plasmids with non-natural replicons such as pUC19. This is a derivative of the ColE1-type pMB1 replicon but in which the rom gene has been deleted, and a nucleotide substitution within RNA II alters its spatial structure in a temperaturedependent manner affecting the interaction between RNA II and the negative regulator RNA I (Minton et al., 1988; LinChao et al., 1992). As a consequence, plasmids with this origin of replication have a copy number abnormally higher. This fact could be responsible for anomalous behavior of the plasmids. Nevertheless, all observations are consistent with plasmid localization by random diffusion and nucleoid exclusion.
Future studies on other small plasmids will contribute to the understanding of their partition dynamics.

\section{IDENTIFICATION OF COMPLETELY SEQUENCED SMALL $K$. pneumoniae PLASMIDS}

A search for $K$. pneumoniae in the NCBI genome database ${ }^{1}$ following the link "Plasmid annotation report ${ }^{2}$ " produced 172 plasmid sequences $25-\mathrm{kb}$ or smaller. After further analysis of

\footnotetext{
${ }^{1}$ https://www.ncbi.nlm.nih.gov/genome/

${ }^{2} \mathrm{https} / / /$ www.ncbi.nlm.nih.gov/genome/plasmids/815?
} 
these sequences, those that had the same number of nucleotides and showed higher than $99 \%$ identity were considered to be the same plasmid (Table 1). The replication regions of pJHCMW1, pKPN2, pKlebB-k17/80, pIP843, pH205, pColEST258, and p15S had been characterized and shown to belong to the ColE1type (Ramirez et al., 2014a). Alignment of the nucleotide sequences of these regions showed high conservation with three sectors with variability (nucleotides 182-208, 402-439, 565-609, Supplementary Figure S1A). Maximum divergence was estimated at 0.446 substitutions per site (Supplementary Figure S1B). Then, the replication regions of all plasmids were compared to the nucleotide sequences of the replication regions of each one of the seven plasmids named above. Among 172 plasmids, those that showed 50\% or higher identity to at least one of the seven plasmids, were considered to possess a ColE1-type replication region (Table 1). Besides, some plasmids did not show $50 \%$ or more identity to the replication regions of either of the seven plasmids used as reference, but they are identified as ColE1-type in GenBank. These plasmids are also considered ColE1-type in Table 1. Other plasmids include putative replication proteins in the GenBank annotations, which suggest initiation of replication mechanism other than ColE1-type (Table 1). In a few other cases there are no indications of the replication mechanism, and in one case both a ColE1-type element and a potential replication protein have been identified (Table 1). The information shown in Table 1 indicates that there is a prevalence of the ColE1type initiation of replication mechanism among sequenced small K. pneumoniae plasmids. To get insights into the evolutionary history of the small plasmids, an alignment-free sequence comparison among its complete sequence were done using Kmacs (Leimeister and Morgenstern, 2014). Subsequently, a hierarchical cluster analysis of studied plasmids was done based on the estimated symmetric distance (Supplementary Figure S2). The results suggest that the seven reference plasmids, pJHCMW1, pKPN2, pKlebB-k17/80, pIP843, pH205, pColEST258, and p15S, represent different lineages of the clustering or "subtypes." The distributions on the clustering of key mobile elements, and resistance genes indicate that they seem to be shared mainly by two of the three "basal" clusters (Table 1), with only a few exceptions. These similarities may reflect vertical inheritance of the shared genes, however, since clustering method is not independent of gene composition we do not continue discussing this issue in order to avoid tautological thinking.

\section{ANTIBIOTIC RESISTANCE GENES AND THEIR INCLUSION WITHIN MOBILE ELEMENTS}

The presence of antibiotic resistance genes and mobile elements were searched using the Multiple Antibiotic Resistance Annotator (MARA) and database (Partridge and Tsafnat, 2018) (Table 1). Seven plasmids include genes coding for KPC enzymes while three and one carry genes coding for CMY and CTX-M enzymes, respectively (Table 1). The bla $a_{\mathrm{CMY}}$ genes are located adjacent to insertion sequences, ISEcP1 in two cases and ISEcp1:ISKpn26 in another (Table 1) (Verdet et al., 2009). The bla $a_{\mathrm{CTX}-\mathrm{M} 15}$ gene, present in pIP843, is located between the insertion sequences ISEcp1 and IS903-C, and the bla $a_{\mathrm{KPC}}$ genes are associated to Tn4401 or related structures (Table 1) (Cao et al., 2002; Gootz et al., 2009). Five plasmids include $b l a_{\mathrm{OXA}}-48$-like genes. Four of them include $b l a_{\mathrm{OXA}}-232$ and

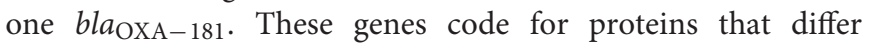
at a single amino acid at position 214, R214 in OXA-181 and S214 in OXA-232 (Potron et al., 2013). These genes are found flanked by ISEcp 1 and an incomplete copy of the erythromycin resistance ereA gene, followed by an imperfect second copy of the ISEcp1 right inverted repeat (Table 1) (Potron et al., 2011).

Four plasmids harbor the complete $b l a_{\mathrm{TEM}-1}$ gene, in two of them within a Tn3-like structure and in pNJST258N5 and pJHCMW1 within Tn1331, a transposon described in detail below. The pDMC1097-20.222kb harbors a truncated bla $a_{\mathrm{TEM}-1}$ gene (Figure 2B). This plasmid includes inverted repeated copies of a transposon-like structure that could have been generated after insertion of IS26 within a Tn3like transposon followed by a recombination process mediated by the insertion sequence (Figure 2B). Analysis of the res region of the mobile elements present in pDMC1097-20.222kb, which includes nucleotides that differ in $\operatorname{Tn} 1, \operatorname{Tn} 2$, and Tn3 (Partridge and Hall, 2005) showed that in one portion the key nucleotides correspond to those in $\mathrm{Tn} 3$ and in another one the key nucleotides are those found in $\operatorname{Tn} 2$ (see Figure 2C).

The $a a c\left(6^{\prime}\right)-I b$ gene, which can be found in two main variants that differ in one amino acid, L or S (T-329 or C329, respectively, in Table 1) (Rather et al., 1992; Ramirez and Tolmasky, 2010), was found in two plasmids within a complete copy of Tn1331 (pJHCMW1) and a transposon with 99\% identity with Tn1331 (pNJST258N5) and in 21 plasmids within Tn1331 derivatives associated to IS26 (see below). The $a a c\left(6^{\prime}\right)-I b$ gene codes for an acetyltransferase that mediates resistance to numerous aminoglycosides including amikacin (variant T-329) or gentamicin (variant C-329) (Ramirez et al., 2013). This gene, originally identified as part of the transposon Tn1331 within pJHCMW1 (Figure 1) and the Serratia marcescens pAZ007 (Tolmasky et al., 1986; Woloj et al., 1986; Tolmasky and Crosa, 1987; Tran van Nhieu and Collatz, 1987; Nobuta et al., 1988; Partridge, 2015), is the most prevalent in amikacinresistant Gram-negative clinical isolates and as such it has been the subject of numerous studies to characterize the AAC $\left(6^{\prime}\right)$-Ib enzyme and to inhibit its effects (Shmara et al., 2001; Pourreza et al., 2005; Lombes et al., 2008; Maurice et al., 2008; Vetting et al., 2008; Soler Bistue et al., 2009; Lin et al., 2014; Li et al., 2015; Lopez et al., 2015; Chiem et al., 2016, 2018; Tran et al., 2018). It may be worthwhile to mention the finding in a $K$. pneumoniae isolate of a variant of $\operatorname{Tn} 1331, \operatorname{Tn} 6238$, that includes the aac $\left(6^{\prime}\right)-I b-c r$ gene, which has two nucleotide changes and codes for an enzyme form that catalyzes acetylation of ciprofloxacin (Quiroga et al., 2015). The only other completely sequenced $K$. pneumoniae plasmid $25-\mathrm{kb}$ or smaller that includes a close relative to 
TABLE 1 | Main characteristics of completely sequenced $K$. pneumoniae plasmids $25-\mathrm{kb}$ or smaller.

\begin{tabular}{|c|c|c|c|c|}
\hline Plasmid name & Size (Kb) & $\begin{array}{l}\text { Mobile elements and resistance } \\
\text { genes }^{2}\end{array}$ & Replication $^{3}$ & Accession number ${ }^{1} /$ References \\
\hline pKPHS6 & 1.308 & & Rep protein & СР003228 \\
\hline p38547-1.476kb & 1.476 & & ColE1-type & СР010388 \\
\hline pMRSN480738_1.6 & 1.551 & & ColE1-type & CP024465 \\
\hline Unnamed & 1.556 & & Rep protein & СР023940 \\
\hline unnamed5 & 1.916 & & Rep protein & СР024520 \\
\hline pUMNturkey9_1 & 1.933 & & ColE1-type & CM003132 \\
\hline pKp_Goe_917-8 & 1.933 & & Rep protein & СР018439 \\
\hline pMYS & 2.014 & & ColE1-type & CP006660 (Hudson et al., 2014) \\
\hline unnamed4 & 2.155 & & ColE1-type & СР023906 \\
\hline plGRK & 2.348 & & Unknown & AY543071 \\
\hline pKP13a & 2.459 & & ColE1-type & CP003996 (Ramos et al., 2014) \\
\hline p38547-2.496kb & 2.496 & & ColE1-type & CP010389 \\
\hline plGMS31 & 2.52 & & Unknown & AY543072 \\
\hline unnamed6 & 2.723 & & ColE1-type & СР024495, СР024488 \\
\hline pMRSN480738_2.8 & 2.78 & & ColE1-type & СР024464 \\
\hline pCAV1042-2781 & 2.781 & & ColE1-type & СР018665 \\
\hline pCAV1596-2927 & 2.927 & & Unknown & CP011643 \\
\hline unnamed10 & 2.936 & & ColE1-type & CP024506 \\
\hline unnamed9 & 3.012 & & ColE1-type & СР024505 \\
\hline pB1020 & 3.174 & & ColE1-type & JQ319772 \\
\hline $\begin{array}{l}\text { pKp04a, pKpNO6-COL, } \\
\text { pCAV1042-3223, pKP13b, unnamed4, } \\
\text { unnamed5, unnamed8 }\end{array}$ & 3.223 & & ColE1-type & $\begin{array}{l}\text { CP012991, CP014305, CP018666, CP024494, } \\
\text { CP024487, CP024514, CP024519, CP024503, } \\
\text { CP003994 (Ramos et al., 2014) }\end{array}$ \\
\hline unnamed7 & 3.336 & & ColE1-type & СР024513 \\
\hline p187-3, pKPHS5 & 3.353 & & ColE1-type & СР025469, СР003227 \\
\hline unnamed6 & 3.377 & & ColE1-type & СР024512 \\
\hline pKPN7 & 3.478 & & ColE1-type & CP000652 \\
\hline unnamed4, unnamed5 & 3.514 & & ColE1-type & СР024493, СР024486, СР024511 \\
\hline pKp_Goe_641-5 & 3.541 & & ColE1-type & CP018739 \\
\hline pKp_Goe_917-7 & 3.559 & & ColE1-type & CP018446 \\
\hline p169 & 3.679 & ISEcp1/b/a $\mathrm{CMY-2-like}$ & ColE1-type & FM246880 (Verdet et al., 2009) \\
\hline pB1021 & 3.692 & & ColE1-type & 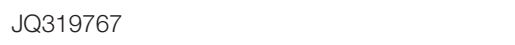 \\
\hline pCAV1344-3741, pCAV1193-3741 & 3.741 & & ColE1-type & CP011619, CP013321 (Sheppard et al., 2016) \\
\hline pKPHS4 & 3.751 & & ColE1-type & СР003226 \\
\hline pKpn23412-4 & 3.777 & ISKpn28 & ColE1-type & CP011316 (Becker et al., 2015) \\
\hline unnamed4 & 3.808 & & ColE1-type & СР023915 \\
\hline unnamed5, unnamed6 & 3.825 & & ColE1-type & $\begin{array}{l}\text { СР024197, СР024569, СР024527, СР024534, } \\
\text { СР024541, СР024555, СР024562, СР024575 }\end{array}$ \\
\hline unnamed3 & 4 & & ColE1-type & СР023908 \\
\hline pKp_Goe_641-4 & 4.052 & & ColE1-type & СР018740 \\
\hline unnamed2, unnamed3 & 4.064 & & ColE1-type & СР024498, СР024518, СР024502 \\
\hline pKp_Goe_070-3 & 4.075 & & ColE1-type & СР018453 \\
\hline unnamed3 & 4.163 & & ColE1-type & СР023945 \\
\hline unnamed4 & 4.166 & & ColE1-type & СР023930 \\
\hline pKPN2 & 4.196 & & ColE1-type & AF300473 (Den'mukhametov et al., 1997) \\
\hline pKpn114 & 4.211 & & ColE1-type & EU932690 \\
\hline unnamed3 & 4.228 & IS1-like & ColE1-type & CP024485 \\
\hline pKp_Goe_579-5 & 4.249 & & ColE1-type & CP018317 \\
\hline pKPN6 & 4.259 & & ColE1-type & СР000651 \\
\hline pCGH25 & 4.27 & qnrD1 & ColE1-type & JQ776509 (Zhang et al., 2013) \\
\hline pKp_Goe_917-6, unnamed5 & 4.51 & & ColE1-type & $\begin{array}{l}\text { СР018440, СР024196, СР024568, СР024526, } \\
\text { СР024533, СР024540, СР024554, СР024561 }\end{array}$ \\
\hline
\end{tabular}


TABLE 1 | Continued

\begin{tabular}{|c|c|c|c|c|}
\hline Plasmid name & Size (Kb) & $\begin{array}{l}\text { Mobile elements and resistance } \\
\text { genes }^{2}\end{array}$ & Replication ${ }^{3}$ & Accession number ${ }^{1} /$ References \\
\hline unnamed4 & 4.66 & & $\begin{array}{l}\text { ColE1-type/Rep } \\
\text { protein }\end{array}$ & $\begin{array}{l}\text { CP024195, СР024567, СР024525, СР024532, } \\
\text { СР024539, СР024553, СР024560 }\end{array}$ \\
\hline $\begin{array}{l}\text { _Plasmid_D_Kpneumoniae } \\
\text { _MS6671 }\end{array}$ & 4.715 & & ColE1-type & LN824137 \\
\hline unnamed5 & 4.744 & & ColE1-type & СР014300 \\
\hline pKP13c & 5.065 & $I S 1 R^{\#}$ & Rep protein & CP003995 (Ramos et al., 2014) \\
\hline pB1019 & 5.225 & & ColE1-type & JQ319775 \\
\hline pKp_Goe_917-5 & 5.234 & & ColE1-type & СР018444 \\
\hline pUUH239.1 & 5.247 & & ColE1-type & CP002473 (Sandegren et al., 2012) \\
\hline pKlebB-k17/80 & 5.258 & & ColE1-type & AF156893 (Riley et al., 2001) \\
\hline unnamed2 & 6.139 & ISEcp1\#/blaOXA-232/ereA3\# & Rep protein & СР016920 \\
\hline $\begin{array}{l}\text { KP-plasmid2, pUCLAOXA232-1, } \\
\text { plasmid4 }\end{array}$ & 6.141 & ISEcp1\#/blaoxA-232/ereA3\# & ColE1-type & $\begin{array}{l}\text { CP012755, CP012562, CP006802 (Doi et al., } \\
\text { 2014; Kwon et al., 2016) }\end{array}$ \\
\hline pOXA-232 & 6.328 & ISEcp1\#/blaOXA-232/ereA3\#/ISEcp1\# & ColE1-type & CM009032 (Mancini et al., 2018) \\
\hline unnamed2 & 6.657 & & ColE1-type & СР024491 \\
\hline plP843 & 7.086 & ISEcp1/blactX-M-17/IS903-C & ColE1-type & AY033516 (Cao et al., 2002) \\
\hline pKP3-A & 7.605 & $\begin{array}{l}\text { ISEcp1 plus } \\
1305 \mathrm{bp} / \text { bla OXA-181/ereA3\# }\end{array}$ & ColE1-type & JN205800 (Potron et al., 2011) \\
\hline Unnamed & 8.187 & & ColE1-type & FJ042668 (Bojer et al., 2010) \\
\hline pH205 & 8.197 & ISEcp1/b/a $\mathrm{CMY}-36$ & ColE1-type & EU331426 (Zioga et al., 2009) \\
\hline tig00003569alt & 8.364 & $\operatorname{Tn} 5403$ & ColE1-type & СР021700 \\
\hline pKPN1482-5 & 9.51 & Tn6901\# & ColE1-type & CP020845 (Long et al., 2017) \\
\hline pRYCKPC3.1 & 9.803 & $\begin{array}{l}\text { Tn4401\#/ISKpn7/ } \\
\text { blakPC-3/ISKpn6/Tn4401\# }\end{array}$ & ColE1-type & GU386376 \\
\hline pMRSN480738_10.0 & 10.046 & & ColE1-type & СР024463 \\
\hline p69-3, p44-3 & 10.06 & & ColE1-type & СР025459, СР025464 \\
\hline unnamed3 & 10.061 & & ColE1-type & СР023944 \\
\hline plasmid 3 & 10.077 & & ColE1-type & СР017388 \\
\hline pKPN1481-5 & 10.373 & $\begin{array}{l}\text { Tn2c\#/IS26/Tn3\#/aac(6')-Ib- } \\
\text { T329/ant(3")-la\# }\end{array}$ & ColE1-type & CP020849 (Long et al., 2017) \\
\hline pNJST258N5 5 & 10.925 & 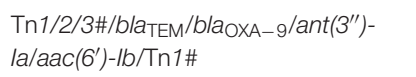 & ColE1-type & CP006924 (Deleo et al., 2014) \\
\hline NY9_p6 & 11.09 & IS26/Tn3\# & ColE1-type & СР015391 \\
\hline pJHCMW1 & 11.354 & $\begin{array}{l}\text { Tn3\#/aac(6')-Ib-T329/ant((3")- } \\
\text { la/blaOXA-9/Tn3\#/blaTEM-1a }\end{array}$ & ColE1-type & AF479774 (Sarno et al., 2002) \\
\hline unnamed4 & 11.972 & $\begin{array}{l}\text { Se.ma.11 (group II intron; also called } \\
\text { Kl.pn.15) }\end{array}$ & ColE1-type & СР023932 \\
\hline pBK13043-3 & 11.984 & ant((3")-la\#/aac(6')-Ib-T329/Tn3\# & ColE1-type & CP020840 (Long et al., 2017) \\
\hline p2 & 12.207 & $\begin{array}{l}\text { Se.ma.I1 (group II intron; also called } \\
\text { Kl.pn.15) }\end{array}$ & ColE1-type & СР006658 \\
\hline
\end{tabular}


TABLE 1 | Continued

\begin{tabular}{|c|c|c|c|c|}
\hline Plasmid name & Size (Kb) & $\begin{array}{l}\text { Mobile elements and resistance } \\
\text { genes }^{2}\end{array}$ & Replication $^{3}$ & Accession number $1 /$ References \\
\hline unnamed3 & 12.273 & $\begin{array}{l}\text { ISEcp1\#/blaOXA-232/ } \\
\text { ereA3\#/ISEcp1\#/blaOXA-232/ereA3\# }\end{array}$ & ColE1-type & СР023924 \\
\hline pKPN1481-4 & 12.376 & IS1R & ColE1-type & CP020850 (Long et al., 2017) \\
\hline p30684_3 & 12.399 & IS1294\#/IS5075\#/IS1294\# & ColE1-type & CP006921 (Deleo et al., 2014) \\
\hline pKPN1482-4 & 12.54 & Tn6901 IR/-/Tn6901 IRL & ColE1-type & CP020846 (Long et al., 2017) \\
\hline p500_1420-13.838kb & 13.838 & $\begin{array}{l}\text { Tn2\#/IS26/ant(3")-la\#/aac(6')-Ib- } \\
\text { C329/Tn3\# }\end{array}$ & ColE1-type & CP011984 (Wright et al., 2014) \\
\hline $\begin{array}{l}\text { p34618-13.841kb, pCAV1453-14, } \\
\text { tig00000004, pBIC-1c, pKPN-294, } \\
\text { pUHKPC07-13.841kb, } \\
\text { pUHKPC33-13.841kb }\end{array}$ & 13.841 & $\begin{array}{l}\text { Tn2\#/IS26/ant(3")-la\#/aac(6')-Ib- } \\
\text { C329/Tn3\# }\end{array}$ & ColE1-type & $\begin{array}{l}\text { CP010394, CP018353, CP020112, CP022576, } \\
\text { CP008832, CP009873, СP011988, CP011993 } \\
\text { (Wright et al., 2014) }\end{array}$ \\
\hline pNJST258N4 & 14.249 & Tn2c\#/Tn1/2/3\#/blatEM-1a & ColE1-type & CP006928 (Deleo et al., 2014) \\
\hline ColE-LS6 & 14.709 & $\begin{array}{l}\text { IS26/Tn2\#/Tn3\#/ant((3")- } \\
\text { la\#/aac(6')-Ib-T329 }\end{array}$ & ColE1-type & JX442973 (Villa et al., 2013) \\
\hline pAAC154-a50 & 15.096 & $\begin{array}{l}\text { Tn3\#/aac(6')-Ib-T329/ant((3")- } \\
\text { la\#/IS26/Tn2\# }\end{array}$ & ColE1-type & CP008828, CP007728 (Snitkin et al., 2012) \\
\hline CN1_p2, pAAC154-a9e & 15.1 & $\begin{array}{l}\text { Tn3\#/aac(6')-Ib-T329/ant(3"')- } \\
\text { la\#/IS26/Tn2\# }\end{array}$ & ColE1-type & CP015384, CP009877 (Conlan et al., 2014) \\
\hline pAAC154 & 15.101 & $\begin{array}{l}\text { Tn3\#/aac(6')-Ib-T329/ant(3"')- } \\
\text { la\#/IS26/Tn2\# }\end{array}$ & ColE1-type & JF828150 (Warburg et al., 2012) \\
\hline pMNCRE69_1 & 15.27 & $\begin{array}{l}\text { IS26/Tn2\#/Tn3\#/ant( }\left(3^{\prime \prime}\right)- \\
\text { la\#/aac(6')-Ib-T329 }\end{array}$ & ColE1-type & CP018425 \\
\hline pMNCRE78_1 & 18.89 & $\begin{array}{l}\text { IS26/Tn2\#/Tn3\#/aac(6')-Ib- } \\
\text { T329/ant((3")-la\#/IS26/Tn2\# }\end{array}$ & ColE1-type & СР018431 \\
\hline pDMC1097-20.222kb ${ }^{4}$ & 20.222 & $\begin{array}{l}\text { Tn1/2/3-like\#/IS26/ } \\
\text { Tn2\#/Tn2\#/IS26/Tn1,2,3-like\# }\end{array}$ & ColE1-type & CP011979 (Wright et al., 2014) \\
\hline pKPN1481-3 & 20.38 & ISKpn28 & ColE1-type & CP020852 (Long et al., 2017) \\
\hline pSLMT & 21.138 & $\begin{array}{l}\text { ISKpn31\#/Tn4401\#/ISKpn7/ } \\
\text { blakPC-2/ISKpn6/Tn4401\#/ } \\
\text { ISKpn31\#/Tn5403\# }\end{array}$ & ColE1-type & HQ589350 \\
\hline tig00000005 & 22.062 & $\begin{array}{l}\text { IS26\#/Tn1/2/3\#/ } \\
\text { bla } \\
\text { ISKM-1a/Tn4401\#/ } \\
\text { ISKn//blaKPC-3/ISKpn6/Tn4401\# }\end{array}$ & ColE1-type & СР020075 \\
\hline unitig_5 & 22.632 & $\begin{array}{l}\text { ISKpn6\#/Tn4401\#/Tn2\#/IS26/ } \\
\text { ant((3")-la\#/aac(6')-Ib- } \\
\text { T329/Tn1\#/Tn4401\#/ISKpn7/ } \\
\text { blakPC-3/ISKpn6\# }\end{array}$ & ColE1-type & СР021756 \\
\hline tig00000005 & 22.633 & $\begin{array}{l}\text { Tn1\#/Tn4401\#/IS } \\
\text { Kpn7/b/aKPC-3/ISKpn6 } \\
\text { /Tn4401\#/Tn2\#/IS26/ant } \\
\text { (3")-la\#/aac(6')-Ib-T329 }\end{array}$ & ColE1-type & СР021548 \\
\hline
\end{tabular}


TABLE 1 | Continued

\begin{tabular}{|c|c|c|c|c|}
\hline Plasmid name & Size (Kb) & $\begin{array}{l}\text { Mobile elements and resistance } \\
\text { genes }^{2}\end{array}$ & Replication ${ }^{3}$ & Accession number ${ }^{1} /$ References \\
\hline p15S & 23.753 & $\begin{array}{l}\text { Tn2\#/IS26/ant(3")-la\#/ } \\
\text { aac(6')-Ib-T329/Tn3\#/ } \\
\text { Tn4401\#/ISKpn7//blakPC-2/ } \\
\text { ISKpn6/Tn4401\#/ }\end{array}$ & ColE1-type & FJ223606 (Gootz et al., 2009) \\
\hline tig00000007_pilon & 24.749 & $\begin{array}{l}\text { Tn4401\#/ISKpn6/blakPC-3/ } \\
\text { ISKpn7/Tn4401\#/Tn2\#/IS26/ } \\
\text { ant(3"')-la\#/aac(6')-Ib-T329/Tn3\# }\end{array}$ & ColE1-type & CP021860 \\
\hline
\end{tabular}

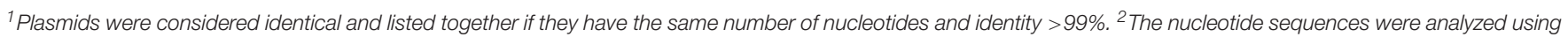

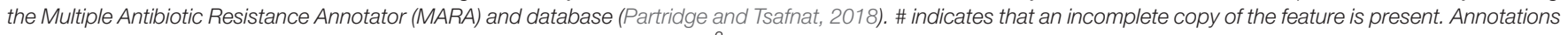

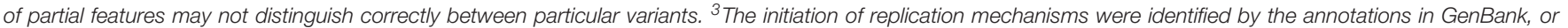

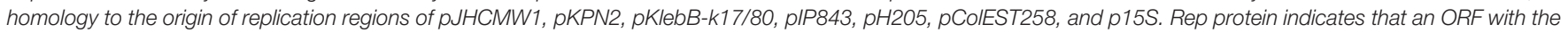

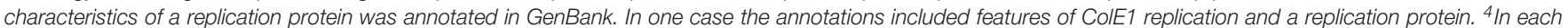

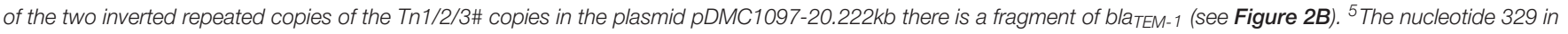
the sequence CP006924 in GenBank is shown as "N."

Tn1331 (99\% identity, called $\operatorname{Tn} 1331$ in this review) in its structure is pNJST258N5, recently found in a carbapenemresistant sequence type (ST) 258 isolate from a patient with urinary tract infection (Chen et al., 2014b; Deleo et al., 2014). A comparison of the pJHCMW1 and pNJST258N5 sequences shows that although they share the Tn1331 transposon, their backbones share homology only at the replication regions and Xer site-specific recombination sites (Figure 2D). Furthermore, these DNA regions are found in opposite orientations with respect to Tn1331. These structural properties suggest that both plasmids were generated independently by insertion of Tn1331 into two different plasmids. The transposon Tn1331 is a derivative of $\operatorname{Tn} 3$ with the addition of a segment including three resistance genes, $a a c\left(6^{\prime}\right)-I b$ (also known as $\left.a a c A 4\right)$, ant $\left(3^{\prime \prime}\right)$ Ia (also known as aadA1) (Ramirez and Tolmasky, 2010),

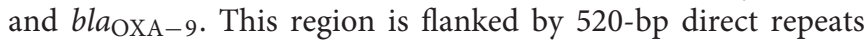
and its structure resembles the variable region of integrons (Tolmasky, 1990; Tolmasky and Crosa, 1993; Ramirez et al., 2008). A detailed description of this segment has been included in previous articles (Tolmasky, 2000; Sarno et al., 2002; Ramirez et al., 2008; Ramirez and Tolmasky, 2010). A derivative of Tn1331, named Tn1331 $\Delta:$ IS26, that has an insertion of IS26 and a deletion that includes part of $\operatorname{ant}\left(3^{\prime \prime}\right)-I a$, the complete $b l a_{\mathrm{OXA}-9}$, and part of bla $a_{\mathrm{TEM}-1}$ (Figure 2E) was first described in pAAC154, and it was later found in several plasmids (Table 1) (Warburg et al., 2012; He et al., 2016). Interestingly, in most cases, the usual flanking direct repeats at the sites of insertion of Tn1331 $\Delta$ :IS26 are missing, probably due to IS26-mediated processes (Iida et al., 1984; Dawes et al., 2010; Harmer and Hall, 2015; He et al., 2015). A truncated version of Tn1331 $\Delta$ :IS26 that lacks the region encompassing IS26 and the terminal fraction of Tn1331 was found in the 11,984-nucleotide pBK130433 (Table 1 and Figure 2E). The recently described precise excision process mediated by IS26 is probably responsible for the generation of the structure found in this plasmid (Harmer and Hall, 2015). The aac $\left(6^{\prime}\right)-I b$ gene was also found associated with other Tn3 and IS26 structures (see Table 1). Although other derivatives of Tn1331 were identified (Tolmasky et al., 1988; Poirel et al., 2006; Rice et al., 2008), none of these elements were detected in fully sequenced $K$. pneumoniae plasmids 25$\mathrm{kb}$ or smaller.

\section{CONCLUDING REMARKS}

Plasmids are known to host genes coding for virulence factors and antibiotic resistance. These genes are usually located within elements that disseminate at the molecular level. As a consequence, the interplay between dissemination between DNA molecules and the ability of plasmids to disseminate at the cellular level practically erase all barriers for genes to reach virtually all bacteria. Recent research about the genetic characteristics of $K$. pneumoniae pathogenic strains shows that this bacterium usually harbors numerous plasmids that can shape its properties as well as the nature of the diseases caused. However, within the variety of plasmids found in this bacterium, most of the attention has been directed to large plasmids that can accumulate numerous genetic determinants, mobile elements, and the information of self-transmission. A revision of the information available shows that smaller plasmids, which tend to possess higher copy numbers, can also be active participants in shaping $K$. pneumoniae strains and their evolution. They can disseminate at the cellular level by mobilization, contribute to plasmid evolution, and enhance gene expression by gene dosage. Despite the small size and limited number of genes they harbor, important resistance genes are usually present in most instances as part of transposons and integron-like structures. All these properties make them important contributors to shaping the biological properties of $K$. pneumoniae and other bacteria of interest to human health including multidrug resistance.

\section{DATA AVAILABILITY STATEMENT}

Publicly available datasets were analyzed in this study. This data can be found here: http://www.ncbi. nlm.nih.gov/genome/plasmids. 


\section{AUTHOR CONTRIBUTIONS}

All the authors contributed equally to the writing of this review.

\section{FUNDING}

Part of the authors' work described in this review was funded by the Public Health Service Grants 2R15AI047115 (MT) and NIH1SC3GM125556-01 (MR) from the National

\section{REFERENCES}

Almaghrabi, R., Clancy, C. J., Doi, Y., Hao, B., Chen, L., Shields, R. K. et al. (2014). Carbapenem-resistant Klebsiella pneumoniae strains exhibit diversity in aminoglycoside-modifying enzymes, which exert differing effects on plazomicin and other agents. Antimicrob. Agents Chemother. 58, 4443-4451. doi: 10.1128/AAC.00099-14

Barre, F. X., Soballe, B., Michel, B., Aroyo, M., Robertson, M., and Sherratt, D. (2001). Circles: the replication-recombination-chromosome segregation connection. Proc. Natl. Acad. Sci. U.S.A. 98, 8189-8195. doi: 10.1073/pnas. 111008998

Baxter, J. C., and Funnell, B. E. (2015). "Plasmid partition mechanisms," in Plasmids. Biology and Impact in Biotechnology and Discovery, eds M. E. Tolmasky, and J. A. Alonso, (Washington, DC: ASM Press), 135-155.

Becker, L., Bunk, B., Eller, C., Steglich, M., Pfeifer, Y., Werner, G., et al. (2015). Complete genome sequence of a CTX-M-15-producing Klebsiella pneumoniae outbreak strain from multilocus sequence type 514. Genome Announc. 3:e00742-15. doi: 10.1128/genomeA.00742-15

Bojer, M. S., Struve, C., Ingmer, H., Hansen, D. S., and Krogfelt, K. A. (2010). Heat resistance mediated by a new plasmid encoded Clp ATPase, ClpK, as a possible novel mechanism for nosocomial persistence of Klebsiella pneumoniae. PLoS One 5:e15467. doi: 10.1371/journal.pone.0015467

Boyd, D. A., Mataseje, L. F., Davidson, R., Delport, J. A., Fuller, J., Hoang, L., et al. (2017). Enterobacter cloacae complex isolates harboring blaNMC-A or blaIMI-type class A carbapenemase genes on novel chromosomal integrative elements and plasmids. Antimicrob. Agents Chemother. 61:e002578-16. doi: 10.1128/AAC.02578-16

Brantl, S. (2014). Plasmid replication control by antisense RNAs. Microbiol. Spectr. 2:PLAS-0001-2013.

Bui, D., Ramiscal, J., Trigueros, S., Newmark, J. S., Do, A., Sherratt, D. J., et al. (2006). Differences in resolution of $m w r$-containing plasmid dimers mediated by the Klebsiella pneumoniae and Escherichia coli XerC recombinases: potential implications in dissemination of antibiotic resistance genes. J. Bacteriol. 188, 2812-2820. doi: 10.1128/jb.188.8.2812-2820.2006

Calfee, D. P. (2017). Recent advances in the understanding and management of Klebsiella pneumoniae. F1000Res. 6:1760. doi: 10.12688/f1000research.11532.1

Calva, E., Silva, C., Zaidi, M. B., Sanchez-Flores, A., Estrada, K., Silva, G. G., et al. (2015). Complete genome sequencing of a multidrug-resistant and humaninvasive Salmonella enterica serovar Typhimurium strain of the emerging sequence type 213 genotype. Genome Announc. 3:e00663-15. doi: 10.1128/ genomeA.00663-15

Cameranesi, M., Moran-Barrio, J., Limansky, A., Repizo, G., and Viale, A. (2018). Site-specific recombination at XerC/D sites mediates the formation and resolution of plasmid co-integrates carrying a blaOXA-58- and TnaphA6resistance module in Acinetobacter baumannii. Front. Microbiol. 9:66. doi: 10. 3389/fmicb.2018.00066

Cao, G., Allard, M. W., Hoffmann, M., Monday, S. R., Muruvanda, T., Luo, Y., et al. (2015). Complete sequences of six IncA/C plasmids of multidrug-resistant Salmonella enterica subsp. enterica Serotype Newport. Genome Announc. 3:e027-15. doi: 10.1128/genomeA.00027-15

Cao, V., Lambert, T., and Courvalin, P. (2002). ColE1-like plasmid pIP843 of Klebsiella pneumoniae encoding extended-spectrum beta-lactamase CTX-M17. Antimicrob. Agents Chemother. 46, 1212-1217. doi: 10.1128/aac.46.5.12121217.2002
Institutes of Health, and Wellcome Trust Investigator Award 099204/Z/12Z (DS).

\section{SUPPLEMENTARY MATERIAL}

The Supplementary Material for this article can be found online at: https://www.frontiersin.org/articles/10.3389/fmicb. 2019.02182/full\#supplementary-material

Chen, L., Mathema, B., Chavda, K. D., Deleo, F. R., Bonomo, R. A., and Kreiswirth, B. N. (2014a). Carbapenemase-producing Klebsiella pneumoniae: molecular and genetic decoding. Trends Microbiol. 22, 686-696. doi: 10.1016/j.tim.2014. 09.003

Chen, L., Mathema, B., Pitout, J. D., Deleo, F. R., and Kreiswirth, B. N. (2014b). Epidemic Klebsiella pneumoniae ST258 is a hybrid strain. mBio 5:e01355-14. doi: 10.1128/mBio.01355-14

Chen, W., Ma, T., Bai, X., Zhang, X., Shen, Y., Lao, M., et al. (2019). Pyogenic liver abscess after pancreaticoduodenectomy: a single-center experience. J. Surg. Res. 239, 67-75. doi: 10.1016/j.jss.2018.12.004

Chen, Y. T., Chang, H. Y., Lai, Y. C., Pan, C. C., Tsai, S. F., and Peng, H. L. (2004). Sequencing and analysis of the large virulence plasmid pLVPK of Klebsiella pneumoniae CG43. Gene 337, 189-198. doi: 10.1016/j.gene.2004. 05.008

Cheng, D. L., Liu, Y. C., Yen, M. Y., Liu, C. Y., and Wang, R. S. (1991). Septic metastatic lesions of pyogenic liver abscess. Their association with Klebsiella pneumoniae bacteremia in diabetic patients. Arch. Intern. Med. 151, 1557-1559. doi: 10.1001/archinte.151.8.1557

Chiem, K., Hue, F., Magallon, J., and Tolmasky, M. E. (2018). Inhibition of aminoglycoside $6^{\prime}$-N-acetyltransferase type Ib-mediated amikacin resistance by zinc complexed with clioquinol, an ionophore active against tumors and neurodegenerative diseases. Int. J. Antimicrob. Agents 51, 271-273. doi: 10. 1016/j.ijantimicag.2017.08.002

Chiem, K., Jani, S., Fuentes, B., Lin, D. L., Rasche, M. E., and Tolmasky, M. E. (2016). Identification of an inhibitor of the aminoglycoside $6^{\prime}$ $N$-acetyltransferase type Ib $\left[\mathrm{AAC}\left(6^{\prime}\right)\right.$-Ib] by glide molecular docking. Medchemcomm 7, 184-189. doi: 10.1039/c5md00316d

Conlan, S., Park, M., Deming, C., Thomas, P. J., Young, A. C., Coleman, H., et al. (2016). Plasmid dynamics in KPC-positive Klebsiella pneumoniae during long-term patient colonization. mBio 7:e00742-16. doi: 10.1128/mBio. 00742-16

Conlan, S., Thomas, P. J., Deming, C., Park, M., Lau, A. F., Dekker, J. P., et al. (2014). Single-molecule sequencing to track plasmid diversity of hospitalassociated carbapenemase-producing Enterobacteriaceae. Sci. Transl. Med. 6:254ra126. doi: 10.1126/scitranslmed.3009845

D’Andrea, M. M., Giani, T., D’arezzo, S., Capone, A., Petrosillo, N., Visca, P., et al. (2009). Characterization of pABVA01, a plasmid encoding the OXA-24 carbapenemase from Italian isolates of Acinetobacter baumannii. Antimicrob. Agents Chemother. 53, 3528-3533. doi: 10.1128/AAC.00178-09

Das, B., Martinez, E., Midonet, C., and Barre, F. X. (2013). Integrative mobile elements exploiting Xer recombination. Trends Microbiol. 21, 23-30. doi: 10. 1016/j.tim.2012.10.003

Dawes, F. E., Kuzevski, A., Bettelheim, K. A., Hornitzky, M. A., Djordjevic, S. P., and Walker, M. J. (2010). Distribution of class 1 integrons with IS26-mediated deletions in their 3'-conserved segments in Escherichia coli of human and animal origin. PLoS One 5:e12754. doi: 10.1371/journal.pone.0012754

de Toro, M., Garcillaon-Barcia, M. P., and De La Cruz, F. (2014). Plasmid diversity and adaptation analyzed by massive sequencing of Escherichia coli plasmids. Microbiol. Spectr. 2:PLAS-0031-2014. doi: 10.1128/microbiolspec.PLAS-00312014

Decre, D., Verdet, C., Emirian, A., Le Gourrierec, T., Petit, J. C., Offenstadt, G., et al. (2011). Emerging severe and fatal infections due to Klebsiella pneumoniae in two university hospitals in France. J. Clin. Microbiol. 49, 3012-3014. doi: 10.1128/JCM.00676-11 
Deleo, F. R., Chen, L., Porcella, S. F., Martens, C. A., Kobayashi, S. D., Porter, A. R., et al. (2014). Molecular dissection of the evolution of carbapenem-resistant multilocus sequence type 258 Klebsiella pneumoniae. Proc. Natl. Acad. Sci. U.S.A. 111, 4988-4993. doi: 10.1073/pnas.1321364111

Den'mukhametov, M. M., Zakharova, M. V., Kravets, A. N., Pertsev, A. V., Sineva, E. V., Repik, A. V., et al. (1997). Characteristics of a plasmid bearing a gene of a restriction modification type II system-the SsoII isoschizomer. Mol. Biol. 31, 831-838.

Dery, K. J., Chavideh, R., Waters, V., Chamorro, R., Tolmasky, L. S., and Tolmasky, M. E. (1997). Characterization of the replication and mobilization regions of the multiresistance Klebsiella pneumoniae plasmid pJHCMW1. Plasmid 38, 97-105. doi: 10.1006/plas.1997.1303

Desmet, S., Nepal, S., Van Dijl, J. M., Van Ranst, M., Chlebowicz, M. A., Rossen, J. W., et al. (2018). Antibiotic resistance plasmids cointegrated into a megaplasmid harbouring the blaOXA-427 carbapenemase gene. Antimicrob. Agents Chemother. 62:e01448-17. doi: 10.1128/AAC.01448-17

Doi, Y., Hazen, T. H., Boitano, M., Tsai, Y. C., Clark, T. A., Korlach, J., et al. (2014). Whole-genome assembly of Klebsiella pneumoniae coproducing NDM-1 and OXA-232 carbapenemases using single-molecule, real-time sequencing. Antimicrob. Agents Chemother. 58, 5947-5953. doi: 10.1128/AAC.03 180-14

Fricke, W. F., Mammel, M. K., Mcdermott, P. F., Tartera, C., White, D. G., Leclerc, J. E., et al. (2011). Comparative genomics of 28 Salmonella enterica isolates: evidence for CRISPR-mediated adaptive sublineage evolution. J. Bacteriol. 193, 3556-3568. doi: 10.1128/JB.00297-11

Garcia-Fernandez, A., Villa, L., Carta, C., Venditti, C., Giordano, A., Venditti, M., et al. (2012). Klebsiella pneumoniae ST258 producing KPC-3 identified in italy carries novel plasmids and OmpK36/OmpK35 porin variants. Antimicrob. Agents Chemother. 56, 2143-2145. doi: 10.1128/AAC.05308-11

Gootz, T. D., Lescoe, M. K., Dib-Hajj, F., Dougherty, B. A., He, W., Della-Latta, P., et al. (2009). Genetic organization of transposase regions surrounding blaKPC carbapenemase genes on plasmids from Klebsiella strains isolated in a New York City hospital. Antimicrob. Agents Chemother. 53, 1998-2004. doi: 10.1128/AAC. 01355-08

Gupta, A., Bhatti, S., Leytin, A., and Epelbaum, O. (2018). Novel complication of an emerging disease: Invasive Klebsiella pneumoniae liver abscess syndrome as a cause of acute respiratory distress syndrome. Clin. Pract. 8:1021. doi: 10.4081/ cp.2018.1021

Harmer, C. J., and Hall, R. M. (2015). IS26-mediated precise excision of the IS26-aphA1a translocatable unit. mBio 6:e01866-15. doi: 10.1128/mBio.01 866-15

He, S., Chandler, M., Varani, A. M., Hickman, A. B., Dekker, J. P., and Dyda, F. (2016). Mechanisms of evolution in high-consequence drug resistance plasmids. mBio 7:e01987-16. doi: 10.1128/mBio.01987-16

He, S., Hickman, A. B., Varani, A. M., Siguier, P., Chandler, M., Dekker, J. P., et al. (2015). Insertion sequence IS26 reorganizes plasmids in clinically isolated multidrug-resistant bacteria by replicative transposition. mBio 6:e00762-15. doi: $10.1128 / \mathrm{mBio} .00762-15$

Hudson, C. M., Bent, Z. W., Meagher, R. J., and Williams, K. P. (2014). Resistance determinants and mobile genetic elements of an NDM-1-encoding Klebsiella pneumoniae strain. PLoS One 9:e99209. doi: 10.1371/journal.pone.0099209

Iida, S., Mollet, B., Meyer, J., and Arber, W. (1984). Functional characterization of the prokaryotic mobile genetic element IS26. Mol. Gen. Genet. 198, 84-89. doi: $10.1007 /$ bf00328705

Jun, J. B. (2018). Klebsiella pneumoniae liver abscess. Infect. Chemother. 50, 210218. doi: 10.3947/ic.2018.50.3.210

Kalpoe, J. S., Sonnenberg, E., Factor, S. H., Del Rio Martin, J., Schiano, T., Patel, G., et al. (2012). Mortality associated with carbapenem-resistant Klebsiella pneumoniae infections in liver transplant recipients. Liver Transpl. 18, 468-474. doi: 10.1002/lt.23374

Kwon, T., Yang, J. W., Lee, S., Yun, M. R., Yoo, W. G., Kim, H. S., et al. (2016). Complete genome sequence of Klebsiella pneumoniae subsp. pneumoniae KP617, coproducing OXA-232 and NDM-1 Carbapenemases, isolated in South Korea. Genome Announc. 4:e01550-15. doi: 10.1128/genomeA.01550-15

Leimeister, C. A., and Morgenstern, B. (2014). Kmacs: the k-mismatch average common substring approach to alignment-free sequence comparison. Bioinformatics 30, 2000-2008. doi: 10.1093/bioinformatics/ btu331
Leong, S. A., Ditta, G. S., and Helinski, D. R. (1982). Heme biosynthesis in Rhizobium. Identification of a cloned gene coding for delta-aminolevulinic acid synthetase from Rhizobium meliloti. J. Biol. Chem. 257, 8724-8730.

Li, B., Zhao, Y., Liu, C., Chen, Z., and Zhou, D. (2014). Molecular pathogenesis of Klebsiella pneumoniae. Future Microbiol. 9, 1071-1081. doi: 10.2217/fmb.14.48

Li, Y., Green, K. D., Johnson, B. R., and Garneau-Tsodikova, S. (2015). Inhibition of aminoglycoside acetyltransferase resistance enzymes by metal salts. Antimicrob. Agents Chemother. 59, 4148-4156. doi: 10.1128/AAC.00885-15

Lilly, J., and Camps, M. (2015). Mechanisms of theta plasmid replication. Microbiol. Spectr. 3:PLAS-0029-2014.

Lin, D. L., Ramirez, M. S., Tran, T., and Tolmasky, M. E. (2013). A cointegrate-like plasmid that facilitates dissemination by conjugation of the extended-spectrum beta-lactamase CTX-M-17. Antimicrob. Agents Chemother. 57, 5191-5192. doi: 10.1128/aac.01365-13

Lin, D. L., Tran, T., Alam, J. Y., Herron, S. R., Ramirez, M. S., and Tolmasky, M. E. (2014). Inhibition of aminoglycoside $6^{\prime}-N$-acetyltransferase type Ib by zinc: reversal of amikacin resistance in Acinetobacter baumannii and Escherichia coli by a zinc ionophore. Antimicrob. Agents Chemother. 58, 4238-4241. doi: 10.1128/AAC.00129-14

Lin-Chao, S., Chen, W. T., and Wong, T. T. (1992). High copy number of the pUC plasmid results from a Rom/Rop-suppressible point mutation in RNA II. Mol. Microbiol. 6, 3385-3393. doi: 10.1111/j.1365-2958.1992.tb02206.x

Liu, C., Zheng, H., Yang, M., Xu, Z., Wang, X., Wei, L., et al. (2015). Genome analysis and in vivo virulence of porcine extraintestinal pathogenic Escherichia coli strain PCN033. BMC Genomics 16:717. doi: 10.1186/s12864-015-1890-9

Liu, P., Li, P., Jiang, X., Bi, D., Xie, Y., Tai, C., et al. (2012). Complete genome sequence of Klebsiella pneumoniae subsp. pneumoniae HS11286, a multidrugresistant strain isolated from human sputum. J. Bacteriol. 194, 1841-1842. doi: 10.1128/JB.00043-12

Lombes, T., Begis, G., Maurice, F., Turcaud, S., Lecourt, T., Dardel, F., et al. (2008). NMR-guided fragment-based approach for the design of AAC $\left(6^{\prime}\right)$-Ib ligands. Chembiochem 9, 1368-1371. doi: 10.1002/cbic.200700677

Long, S. W., Olsen, R. J., Eagar, T. N., Beres, S. B., Zhao, P., Davis, J. J., et al. (2017). Population genomic analysis of 1,777 extended-spectrum beta-lactamase-producing Klebsiella pneumoniae isolates, Houston, Texas: unexpected abundance of clonal group 307. mBio 8:e00489-17. doi: 10.1128/ mBio.00489-17

Lopez, C., Arivett, B. A., Actis, L. A., and Tolmasky, M. E. (2015). Inhibition of AAC $\left(6^{\prime}\right)$-Ib-mediated resistance to amikacin in Acinetobacter baumannii by an antisense peptide-conjugated 2',4'-bridged nucleic acid-NC-DNA hybrid oligomer. Antimicrob. Agents Chemother. 59, 5798-5803. doi: 10.1128/AAC. 01304- 15

Mancini, S., Poirel, L., Tritten, M. L., Lienhard, R., Bassi, C., and Nordmann, P. (2018). Emergence of an MDR Klebsiella pneumoniae ST231 producing OXA232 and RmtF in Switzerland. J. Antimicrob. Chemother. 73, 821-823. doi: $10.1093 / \mathrm{jac} / \mathrm{dkx} 428$

Marr, C. M., and Russo, T. A. (2019). Hypervirulent Klebsiella pneumoniae: a new public health threat. Expert Rev. Anti Infect. Ther. 17, 71-73. doi: 10.1080/ 14787210.2019.1555470

Martel, A., Butet, B., Ramel, J. C., Martiano, D., and Baillif, S. (2017). Medical management of a subretinal Klebsiella pneumoniae abscess with excellent visual outcome without performing vitrectomy. J. Fr. Ophtalmol. 40, 876-881. doi: 10.1016/j.jfo.2017.06.007

Martin, R. M., and Bachman, M. A. (2018). Colonization, infection, and the accessory genome of Klebsiella pneumoniae. Front. Cell Infect. Microbiol. 8:4. doi: 10.3389/fcimb.2018.00004

Mathers, A. J., Peirano, G., and Pitout, J. D. (2015). The role of epidemic resistance plasmids and international high-risk clones in the spread of multidrug-resistant Enterobacteriaceae. Clin. Microbiol. Rev. 28, 565-591. doi: 10.1128/CMR.00 116-14

Maurice, F., Broutin, I., Podglajen, I., Benas, P., Collatz, E., and Dardel, F. (2008). Enzyme structural plasticity and the emergence of broad-spectrum antibiotic resistance. EMBO Rep. 9, 344-349. doi: 10.1038/embor.2008.9

Merino, M., Acosta, J., Poza, M., Sanz, F., Beceiro, A., Chaves, F., et al. (2010). OXA-24 carbapenemase gene flanked by XerC/XerD-like recombination sites in different plasmids from different Acinetobacter species isolated during a nosocomial outbreak. Antimicrob. Agents Chemother. 54, 2724-2727. doi: 10. 1128/AAC.01674-09 
Midonet, C., and Barre, F. X. (2014). Xer site-specific recombination: promoting vertical and horizontal transmission of genetic information. Microbiol. Spectr. 2:MDNA3-0056-2014. doi: 10.1128/microbiolspec.MDNA3-0056-2014

Midonet, C., and Barre, F. X. (2016). How Xer-exploiting mobile elements overcome cellular control. Proc. Natl. Acad. Sci. U.S.A. 113, 8343-8345. doi: 10.1073/pnas.1608539113

Midonet, C., Miele, S., Paly, E., Guerois, R., and Barre, F. X. (2019). The TLCPhi satellite phage harbors a Xer recombination activation factor. Proc. Natl. Acad. Sci. U.S.A. 116, 18391-18396.

Million-Weaver, S., and Camps, M. (2014). Mechanisms of plasmid segregation: have multicopy plasmids been overlooked? Plasmid 75, 27-36. doi: 10.1016/j. plasmid.2014.07.002

Minton, N., Chambers, S., Prior, S., Cole, S. T., and Garnier, T. (1988). Copy number and mobilization properties of pUC plasmid. Focus 10:56. doi: 10.1128/ AEM.01574-15

Nassif, X., Fournier, J. M., Arondel, J., and Sansonetti, P. J. (1989a). Mucoid phenotype of Klebsiella pneumoniae is a plasmid-encoded virulence factor. Infect. Immun. 57, 546-552.

Nassif, X., Honore, N., Vasselon, T., Cole, S. T., and Sansonetti, P. J. (1989b). Positive control of colanic acid synthesis in Escherichia coli by rmpA and $r m p B$, two virulence-plasmid genes of Klebsiella pneumoniae. Mol. Microbiol. 3, 1349-1359. doi: 10.1111/j.1365-2958.1989.tb00116.x

Nassif, X., and Sansonetti, P. J. (1986). Correlation of the virulence of Klebsiella pneumoniae $\mathrm{K} 1$ and $\mathrm{K} 2$ with the presence of a plasmid encoding aerobactin. Infect. Immun. 54, 603-608.

Navon-Venezia, S., Kondratyeva, K., and Carattoli, A. (2017). Klebsiella pneumoniae: a major worldwide source and shuttle for antibiotic resistance. FEMS Microbiol. Rev. 41, 252-275. doi: 10.1093/femsre/fux013

Ncbi_Resource_Coordinators, (2018). Database resources of the national center for biotechnology information. Nucleic Acids Res. 46, D8-D13. doi: 10.1093/nar/ gkx1095

Nobuta, K., Tolmasky, M. E., Crosa, L. M., and Crosa, J. H. (1988). Sequencing and expression of the $6^{\prime}-N$-acetyltransferase gene of transposon Tn 1331 from Klebsiella pneumoniae. J. Bacteriol. 170, 3769-3773.

O’Brien, F. G., Yui Eto, K., Murphy, R. J., Fairhurst, H. M., Coombs, G. W., Grubb, W. B., et al. (2015). Origin-of-transfer sequences facilitate mobilisation of nonconjugative antimicrobial-resistance plasmids in Staphylococcus aureus. Nucleic Acids Res. 43, 7971-7983. doi: 10.1093/nar/gkv755

Osei Sekyere, J., and Amoako, D. G. (2017). Genomic and phenotypic characterisation of fluoroquinolone resistance mechanisms in Enterobacteriaceae in Durban. South Africa. PLoS One 12:e0178888. doi: 10.1371/journal.pone.0178888

Osman, K., Srinivasa, S., and Koea, J. (2018). Liver abscess: contemporary presentation and management in a western population. N. Z. Med. J. 131, 65-70.

Partridge, S. R. (2015). What's in a name? ISSwil corresponds to transposons related to Tn2 and Tn3. mBio 6:e01344-15. doi: 10.1128/mBio.01344-15

Partridge, S. R., and Hall, R. M. (2005). Evolution of transposons containing blaTEM genes. Antimicrob. Agents Chemother. 49, 1267-1268. doi: 10.1128/ aac.49.3.1267-1268.2005

Partridge, S. R., and Tsafnat, G. (2018). Automated annotation of mobile antibiotic resistance in Gram-negative bacteria: the multiple antibiotic resistance annotator (MARA) and database. J. Antimicrob. Chemother. 73, 883-890. doi: 10.1093/jac/dkx513

Pasquali, F., Kehrenberg, C., Manfreda, G., and Schwarz, S. (2005). Physical linkage of Tn3 and part of Tn1721 in a tetracycline and ampicillin resistance plasmid from Salmonella Typhimurium. J. Antimicrob. Chemother. 55, 562-565. doi: $10.1093 / \mathrm{jac} / \mathrm{dkh} 553$

Peirano, G., Bradford, P. A., Kazmierczak, K. M., Chen, L., Kreiswirth, B. N., and Pitout, J. D. (2017). Importance of clonal complex 258 and IncFK2-like plasmids among a global collection of Klebsiella pneumoniae with blaKPC. Antimicrob. Agents Chemother. 61:e02610-16. doi: 10.1128/AAC.02610-16

Pham, H., Dery, K. J., Sherratt, D. J., and Tolmasky, M. E. (2002). Osmoregulation of dimer resolution at the plasmid pJHCMW1 $\mathrm{mwr}$ locus by Escherichia coli XerCD recombination. J. Bacteriol. 184, 1607-1616. doi: 10.1128/jb.184.6. $1607-1616.2002$
Pogliano, J., Ho, T. Q., Zhong, Z., and Helinski, D. R. (2001). Multicopy plasmids are clustered and localized in Escherichia coli. Proc. Natl. Acad. Sci. U.S.A. 98, 4486-4491. doi: 10.1073/pnas.081075798

Poirel, L., Cabanne, L., Collet, L., and Nordmann, P. (2006). Class II transposon-borne structure harboring metallo-beta-lactamase gene blaVIM-2 in Pseudomonas putida. Antimicrob. Agents Chemother. 50, 2889-2891. doi: 10.1128/aac.00398-06

Porres-Osante, N., Azcona-Gutierrez, J. M., Rojo-Bezares, B., Undabeitia, E., Torres, C., and Saenz, Y. (2014). Emergence of a multiresistant KPC-3 and VIM-1 carbapenemase-producing Escherichia coli strain in Spain. J. Antimicrob. Chemother. 69, 1792-1795. doi: 10.1093/jac/dku055

Potron, A., Nordmann, P., Lafeuille, E., Al Maskari, Z., Al Rashdi, F., and Poirel, L. (2011). Characterization of OXA-181, a carbapenem-hydrolyzing class D beta-lactamase from Klebsiella pneumoniae. Antimicrob. Agents Chemother. 55, 4896-4899. doi: 10.1128/AAC.00481-11

Potron, A., Rondinaud, E., Poirel, L., Belmonte, O., Boyer, S., Camiade, S., et al. (2013). Genetic and biochemical characterisation of OXA-232, a carbapenemhydrolysing class D beta-lactamase from Enterobacteriaceae. Int. J. Antimicrob. Agents 41, 325-329. doi: 10.1016/j.ijantimicag.2012.11.007

Pourreza, A., Witherspoon, M., Fox, J., Newmark, J., Bui, D., and Tolmasky, M. E. (2005). Mutagenesis analysis of a conserved region involved in acetyl coenzyme A binding in the aminoglycoside $6^{\prime}-N$-acetyltransferase type Ib encoded by plasmid pJHCMW1. Antimicrob. Agents Chemother. 49, 2979-2982. doi: 10. 1128/aac.49.7.2979-2982.2005

Prokesch, B. C., Tekippe, M., Kim, J., Raj, P., Tekippe, E. M., and Greenberg, D. E. (2016). Primary osteomyelitis caused by hypervirulent Klebsiella pneumoniae. Lancet Infect. Dis. 16, e190-e195. doi: 10.1016/S1473-3099(16)30021-4

Quiroga, M. P., Orman, B., Errecalde, L., Kaufman, S., and Centron, D. (2015). Characterization of Tn6238 with a new allele of aac (6')-Ib-cr. Antimicrob. Agents Chemother. 59, 2893-2897. doi: 10.1128/AAC.03213-14

Ramirez, M. S., Nikolaidis, N., and Tolmasky, M. E. (2013). Rise and dissemination of aminoglycoside resistance: the $a a c\left(6^{\prime}\right)-I b$ paradigm. Front. Microbiol. 4:121. doi: 10.3389/fmicb.2013.00121

Ramirez, M. S., Parenteau, T. R., Centron, D., and Tolmasky, M. E. (2008). Functional characterization of Tn 1331 gene cassettes. J. Antimicrob. Chemother. 62, 669-673. doi: 10.1093/jac/dkn279

Ramirez, M. S., and Tolmasky, M. E. (2010). Aminoglycoside modifying enzymes. Drug Resist. Updat. 13, 151-171. doi: 10.1016/j.drup.2010.08.003

Ramirez, M. S., Traglia, G. M., Lin, D. L., Tran, T., and Tolmasky, M. E. (2014a). Plasmid-mediated antibiotic resistance and virulence in Gram-negatives: the Klebsiella pneumoniae paradigm. Microbiol. Spectr. 2:PLAS-0016-2013.

Ramirez, M. S., Xie, G., Johnson, S., Davenport, K., Van Duin, D., Perez, F., et al. (2014b). Genome sequences of two carbapenemase-resistant Klebsiella pneumoniae ST258 isolates. Genome Announc. 2:e0558-14. doi: 10.1128/ genomeA.00558-14

Ramirez, M. S., Xie, G., Marshall, S. H., Hujer, K. M., Chain, P. S., Bonomo, R. A., et al. (2012). Multidrug-resistant (MDR) Klebsiella pneumoniae clinical isolates: a zone of high heterogeneity (HHZ) as a tool for epidemiological studies. Clin. Microbiol. Infect. 18, E254-E258. doi: 10.1111/j.1469-0691.2012.03886.x

Ramirez, M. S., Xie, G., Traglia, G. M., Johnson, S. L., Davenport, K. W., Van Duin, D., et al. (2016). Whole-genome comparative analysis of two carbapenemresistant ST-258 Klebsiella pneumoniae strains isolated during a North-Eastern Ohio outbreak: differences within the high heterogeneity zones. Genome Biol. Evol. 8, 2036-2043. doi: 10.1093/gbe/evw135

Ramos, P. I., Picao, R. C., Almeida, L. G., Lima, N. C., Girardello, R., Vivan, A. C., et al. (2014). Comparative analysis of the complete genome of KPC-2producing Klebsiella pneumoniae Kp13 reveals remarkable genome plasticity and a wide repertoire of virulence and resistance mechanisms. BMC Genomics 15:54. doi: 10.1186/1471-2164-15-54

Ramsay, J. P., Kwong, S. M., Murphy, R. J., Yui Eto, K., Price, K. J., Nguyen, Q. T., et al. (2016). An updated view of plasmid conjugation and mobilization in Staphylococcus. Mob. Genet. Elements 6:e1208317. doi: 10.1080/2159256X.2016. 1208317

Rashid, T., Ebringer, A., and Wilson, C. (2016). The link between Klebsiella and ankylosing spondylitis in worldwide geographical locations. Curr. Rheumatol. Rev. 12, 223-231. doi: 10.2174/1573397112666160331143722 
Rashid, T., Wilson, C., and Ebringer, A. (2013). The link between ankylosing spondylitis, Crohn's disease, Klebsiella, and starch consumption. Clin. Dev. Immunol. 2013:872632. doi: 10.1155/2013/872632

Rather, P. N., Munayyer, H., Mann, P. A., Hare, R. S., Miller, G. H., and Shaw, K. J. (1992). Genetic analysis of bacterial acetyltransferases: identification of amino acids determining the specificities of the aminoglycoside $6^{\prime}-N$-acetyltransferase Ib and IIa proteins. J. Bacteriol. 174, 3196-3203. doi: 10.1128/jb.174.10.31963203.1992

Reyes-Lamothe, R., Tran, T., Meas, D., Lee, L., Li, A. M., Sherratt, D. J., et al. (2014). High-copy bacterial plasmids diffuse in the nucleoid-free space, replicate stochastically and are randomly partitioned at cell division. Nucleic Acids Res. 42, 1042-1051. doi: 10.1093/nar/gkt918

Rice, L. B., Carias, L. L., Hutton, R. A., Rudin, S. D., Endimiani, A., and Bonomo, R. A. (2008). The KQ element, a complex genetic region conferring transferable resistance to carbapenems, aminoglycosides, and fluoroquinolones in Klebsiella pneumoniae. Antimicrob. Agents Chemother. 52, 3427-3429. doi: 10.1128/AAC. 00493-08

Riley, M. A., Pinou, T., Wertz, J. E., Tan, Y., and Valletta, C. M. (2001). Molecular characterization of the klebicin B plasmid of Klebsiella pneumoniae. Plasmid 45, 209-221. doi: 10.1006/plas.2001.1519

Robinow, C., and Kellenberger, E. (1994). The bacterial nucleoid revisited. Microbiol. Rev. 58, 211-232.

Rodriguez-Beltran, J., Hernandez-Beltran, J. C. R., Delafuente, J., Escudero, J. A., Fuentes-Hernandez, A., Maclean, R. C., et al. (2018). Multicopy plasmids allow bacteria to escape from fitness trade-offs during evolutionary innovation. Nat. Ecol. Evol. 2, 873-881. doi: 10.1038/s41559-018-0529-z

Rojas, L. J., Hujer, A. M., Rudin, S. D., Wright, M. S., Domitrovic, T. N., Marshall, S. H., et al. (2017a). NDM-5 and OXA-181 beta-lactamases, a significant threat continues to spread in the Americas. Antimicrob. Agents Chemother. 61:e0454-17. doi: 10.1128/AAC.00454-17

Rojas, L. J., Weinstock, G. M., De La Cadena, E., Diaz, L., Rios, R., Hanson, B. M., et al. (2017b). An analysis of the epidemic of Klebsiella pneumoniae carbapenemase-producing K. pneumoniae: convergence of two evolutionary mechanisms creates the "perfect storm". J. Infect. Dis. 217, 82-92. doi: 10.1093/ infdis/jix 524

Rozwandowicz, M., Brouwer, M. S. M., Fischer, J., Wagenaar, J. A., Gonzalez-Zorn, B., Guerra, B., et al. (2018). Plasmids carrying antimicrobial resistance genes in Enterobacteriaceae. J. Antimicrob Chemother. 73, 1121-1137. doi: 10.1093/jac/ $\mathrm{dkx} 488$

Ruppe, E., Olearo, F., Pires, D., Baud, D., Renzi, G., Cherkaoui, A., et al. (2017), Clonal or not clonal? Investigating hospital outbreaks of KPC-producing Klebsiella pneumoniae with whole-genome sequencing. Clin. Microbiol. Infect. 23, 470-475. doi: 10.1016/j.cmi.2017.01.015

Sandegren, L., and Andersson, D. I. (2009). Bacterial gene amplification: implications for the evolution of antibiotic resistance. Nat. Rev. Microbiol. 7, 578-588. doi: 10.1038/nrmicro2174

Sandegren, L., Linkevicius, M., Lytsy, B., Melhus, A., and Andersson, D. I. (2012). Transfer of an Escherichia coli ST131 multiresistance cassette has created a Klebsiella pneumoniae-specific plasmid associated with a major nosocomial outbreak. J. Antimicrob. Chemother. 67, 74-83. doi: 10.1093/jac/dkr405

Sarno, R., Mcgillivary, G., Sherratt, D. J., Actis, L. A., and Tolmasky, M. E. (2002). Complete nucleotide sequence of Klebsiella pneumoniae multiresistance plasmid pJHCMW1. Antimicrob. Agents Chemother. 46, 3422-3427. doi: 10. 1128/aac.46.11.3422-3427.2002

Sheppard, A. E., Stoesser, N., Sebra, R., Kasarskis, A., Deikus, G., Anson, L., et al. (2016). Complete genome sequence of KPC-producing Klebsiella pneumoniae strain CAV1193. Genome Announc. 4:e01649-15. doi: 10.1128/genomeA. 01649-15

Sherratt, D. J., Lau, I. F., and Barre, F. X. (2001). Chromosome segregation. Curr. Opin. Microbiol. 4, 653-659.

Shmara, A., Weinsetel, N., Dery, K. J., Chavideh, R., and Tolmasky, M. E. (2001). Systematic analysis of a conserved region of the aminoglycoside $6^{\prime}-\mathrm{N}$ acetyltransferase type Ib. Antimicrob. Agents Chemother. 45, 3287-3292. doi: 10.1128/aac.45.12.3287-3292.2001

Shon, A. S., Bajwa, R. P., and Russo, T. A. (2013). Hypervirulent (hypermucoviscous) Klebsiella pneumoniae: a new and dangerous breed. Virulence 4, 107-118. doi: 10.4161/viru.22718
Snitkin, E. S., Zelazny, A. M., Thomas, P. J., Stock, F., Henderson, D. K., Palmore, T. N., et al. (2012). Tracking a hospital outbreak of carbapenemresistant Klebsiella pneumoniae with whole-genome sequencing. Sci. Transl. Med. 4:148ra116. doi: 10.1126/scitranslmed.3004129

Sobirk, S. K., Struve, C., and Jacobsson, S. G. (2010). Primary Klebsiella pneumoniae liver abscess with metastatic spread to lung and eye, a North-European case report of an emerging syndrome. Open Microbiol. J. 4, 5-7. doi: 10.2174/ 1874285801004010005

Soler Bistue, A. J., Birshan, D., Tomaras, A. P., Dandekar, M., Tran, T., Newmark, J., et al. (2008). Klebsiella pneumoniae multiresistance plasmid pMET1: similarity with the Yersinia pestis plasmid pCRY and integrative conjugative elements. PLoS One 3:e1800. doi: 10.1371/journal.pone.0001800

Soler Bistue, A. J., Martin, F. A., Vozza, N., Ha, H., Joaquin, J. C., Zorreguieta, A., et al. (2009). Inhibition of $a a c\left(6^{\prime}\right)$-Ib-mediated amikacin resistance by nucleaseresistant external guide sequences in bacteria. Proc. Natl. Acad. Sci. U.S.A. 106, 13230-13235. doi: 10.1073/pnas.0906529106

Standley, M. S., Million-Weaver, S., Alexander, D. L., Hu, S., and Camps, M. (2019). Genetic control of ColE1 plasmid stability that is independent of plasmid copy number regulation. Curr. Genet. 65, 179-192. doi: 10.1007/s00294-018-0858-0

Sun, Q., Lan, R., Wang, J., Xia, S., Wang, Y., Wang, Y., et al. (2013). Identification and characterization of a novel Shigella flexneri serotype Yv in China. PLoS One 8:e70238. doi: 10.1371/journal.pone.0070238

Tolmasky, M. E. (1990). Sequencing and expression of aadA, bla, and tnpR from the multiresistance transposon Tn1331. Plasmid 24, 218-226. doi: 10.1016/0147619x(90)90005-w

Tolmasky, M. E. (2000). Bacterial resistance to aminoglycosides and beta-lactams: the Tn1331 transposon paradigm. Front. Biosci. 5:D20-D29. doi: 10.2741/ tolmasky

Tolmasky, M. E., Actis, L. A., and Crosa, J. H. (2010). "Plasmid DNA replication," in Encyclopedia of Industrial Biotechnology: Bioprocess, Bioseparation, and Cell Technology, ed. M. Flickinger, (New York, NY: John Wiley and Sons, Inc.), 3931-3953.

Tolmasky, M. E., Chamorro, R. M., Crosa, J. H., and Marini, P. M. (1988). Transposon-mediated amikacin resistance in Klebsiella pneumoniae. Antimicrob. Agents Chemother. 32, 1416-1420. doi: 10.1128/aac.32.9.1416

Tolmasky, M. E., Colloms, S., Blakely, G., and Sherratt, D. J. (2000). Stability by multimer resolution of pJHCMW 1 is due to the $\mathrm{Tn} 1331$ resolvase and not to the Escherichia coli Xer system. Microbiology 146, 581-589. doi: 10.1099/00221287146-3-581

Tolmasky, M. E., and Crosa, J. H. (1987). Tn1331, a novel multiresistance transposon encoding resistance to amikacin and ampicillin in Klebsiella pneumoniae. Antimicrob. Agents Chemother. 31, 1955-1960. doi: 10.1128/aac. 31.12 .1955

Tolmasky, M. E., and Crosa, J. H. (1993). Genetic organization of antibiotic resistance genes $\left(a a c\left(6^{\prime}\right)-I b\right.$, aadA, and oxa9) in the multiresistance transposon Tn1331. Plasmid 29, 31-40. doi: 10.1006/plas.1993.1004

Tolmasky, M. E., Roberts, M., Woloj, M., and Crosa, J. H. (1986). Molecular cloning of amikacin resistance determinants from a Klebsiella pneumoniae plasmid. Antimicrob. Agents Chemother. 30, 315-320. doi: 10.1128/aac. 30.2.315

Tran, T., Andres, P., Petroni, A., Soler-Bistue, A., Albornoz, E., Zorreguieta, A., et al. (2012). Small plasmids harboring qnrB19: a model for plasmid evolution mediated by site-specific recombination at oriT and Xer sites. Antimicrob. Agents Chemother. 56, 1821-1827. doi: 10.1128/AAC.06036-11

Tran, T., Chiem, K., Jani, S., Arivett, B. A., Lin, D. L., Lad, R., et al. (2018). Identification of a small molecule inhibitor of the aminoglycoside $6^{\prime}-\mathrm{N}$ acetyltransferase type $\mathrm{Ib}\left[\mathrm{AAC}\left(6^{\prime}\right)-\mathrm{Ib}\right]$ using mixture-based combinatorial libraries. Int. J. Antimicrob. Agents 51, 752-761. doi: 10.1016/j.ijantimicag.2018. 01.019

Tran, T., Sherratt, D. J., and Tolmasky, M. E. (2010). fpr, a deficient Xer recombination site from a Salmonella plasmid, fails to confer stability by dimer resolution: comparative studies with the pJHCMW1 $m w r$ site. J. Bacteriol. 192, 883-887. doi: 10.1128/JB.01082-09

Tran, van Nhieu, G., and Collatz, E. (1987). Primary structure of an aminoglycoside $6^{\prime}$ - $N$-acetyltransferase AAC $\left(6^{\prime}\right)-4$, fused in vivo with the signal peptide of the Tn3-encoded beta-lactamase. J. Bacteriol. 169, 5708-5714. doi: 10.1128/jb.169. $12.5708-5714.1987$ 
Trigueros, S., Tran, T., Sorto, N., Newmark, J., Colloms, S. D., Sherratt, D. J., et al. (2009). mwr Xer site-specific recombination is hypersensitive to DNA supercoiling. Nucleic Acids Res. 37, 3580-3587. doi: 10.1093/nar/ gkp208

Turton, J. F., Payne, Z., Coward, A., Hopkins, K. L., Turton, J. A., Doumith, M., et al. (2018). Virulence genes in isolates of Klebsiella pneumoniae from the UK during 2016, including among carbapenemase gene-positive hypervirulent K1ST23 and 'non-hypervirulent' types ST147. ST15 and ST383. J. Med. Microbiol .67, 118-128. doi: 10.1099/jmm.0.000653

Verdet, C., Gautier, V., Chachaty, E., Ronco, E., Hidri, N., Decre, D., et al. (2009). Genetic context of plasmid-carried blaCMY-2-like genes in Enterobacteriaceae. Antimicrob. Agents Chemother. 53, 4002-4006. doi: 10.1128/AAC.00753-08

Vetting, M. W., Park, C. H., Hegde, S. S., Jacoby, G. A., Hooper, D. C., and Blanchard, J. S. (2008). Mechanistic and structural analysis of aminoglycoside $N$-acetyltransferase $\mathrm{AAC}\left(6^{\prime}\right)$-Ib and its bifunctional, fluoroquinolone-active AAC(6')-Ib-cr variant. Biochemistry 47, 9825-9835. doi: 10.1021/bi800664x

Villa, L., Capone, A., Fortini, D., Dolejska, M., Rodriguez, I., Taglietti, F., et al. (2013). Reversion to susceptibility of a carbapenem-resistant clinical isolate of Klebsiella pneumoniae producing KPC-3. J. Antimicrob. Chemother. 68, 2482-2486. doi: 10.1093/jac/dkt235

Wacharotayankun, R., Arakawa, Y., Ohta, M., Tanaka, K., Akashi, T., Mori, M., et al. (1993). Enhancement of extracapsular polysaccharide synthesis in Klebsiella pneumoniae by RmpA2, which shows homology to NtrC and FixJ. Infect. Immun. 61, 3164-3174.

Wang, Y., Penkul, P., and Milstein, J. N. (2016). Quantitative localization microscopy reveals a novel organization of a high-copy number plasmid. Biophys. J. 111, 467-479. doi: 10.1016/j.bpj.2016.06.033

Warburg, G., Hidalgo-Grass, C., Partridge, S. R., Tolmasky, M. E., Temper, V., Moses, A. E., et al. (2012). A carbapenem-resistant Klebsiella pneumoniae epidemic clone in Jerusalem: sequence type 512 carrying a plasmid encoding aac $\left(6^{\prime}\right)$-Ib. J. Antimicrob. Chemother. 67, 898-901. doi: 10.1093/jac/dkr552

Willumeit, R., Burkhardt, N., Junemann, R., Wadzack, J., Nierhaus, K., and Stuhrmann, H. (1997). Localization of proteins and tRNA molecules in the 70 S ribosome of the Escherichia coli bacteria with polarized neutron scattering. J. Appl. Cryst. 30, 1125-1131. doi: 10.1107/s002188989700157x

Woloj, M., Tolmasky, M. E., Roberts, M. C., and Crosa, J. H. (1986). Plasmidencoded amikacin resistance in multiresistant strains of Klebsiella pneumoniae isolated from neonates with meningitis. Antimicrob. Agents Chemother. 29, 315-319. doi: 10.1128/aac.29.2.315

Wright, M. S., Perez, F., Brinkac, L., Jacobs, M. R., Kaye, K., Cober, E., et al. (2014). Population structure of KPC-producing Klebsiella pneumoniae isolates from midwestern U.S. hospitals. Antimicrob. Agents Chemother. 58, 4961-4965. doi: 10.1128/AAC.00125-14

Xie, G., Ramirez, M. S., Marshall, S. H., Hujer, K. M., Lo, C. C., Johnson, S., et al. (2013). Genome sequences of two Klebsiella pneumoniae isolates from different geographical regions, Argentina (strain JHCK1) and the United States (strain VA360). Genome Announc. 1:e00168-13. doi: 10.1128/genomeA.00168-13

Yao, H., Qin, S., Chen, S., Shen, J., and Du, X. D. (2018). Emergence of carbapenemresistant hypervirulent Klebsiella pneumoniae. Lancet Infect. Dis. 18:25. doi: 10.1016/s1473-3099(17)30628-x

Yao, S., Helinski, D. R., and Toukdarian, A. (2007). Localization of the naturally occurring plasmid ColE1 at the cell pole. J. Bacteriol. 189, 1946-1953. doi: 10.1128/jb.01451-06

Ye, C., Lan, R., Xia, S., Zhang, J., Sun, Q., Zhang, S., et al. (2010). Emergence of a new multidrug-resistant serotype $\mathrm{X}$ variant in an epidemic clone of Shigella flexneri. J. Clin. Microbiol. 48, 419-426. doi: 10.1128/JCM. 00614-09

Zakharova, M. V., Beletskaya, I. V., Denjmukhametov, M. M., Yurkova, T. V., Semenova, L. M., Shlyapnikov, M. G., et al. (2002). Characterization of pECL18 and pKPN2: a proposed pathway for the evolution of two plasmids that carry identical genes for a Type II restriction-modification system. Mol. Genet. Genomics 267, 171-178. doi: 10.1007/s00438-002-0644-y

Zhan, L., Wang, S., Guo, Y., Jin, Y., Duan, J., Hao, Z., et al. (2017). Outbreak by hypermucoviscous Klebsiella pneumoniae ST11 isolates with carbapenem resistance in a tertiary hospital in China. Front. Cell Infect. Microbiol. 7:182. doi: 10.3389/fcimb.2017.00182.a

Zhang, S., Sun, J., Liao, X. P., Hu, Q. J., Liu, B. T., Fang, L. X., et al. (2013). Prevalence and plasmid characterization of the $q n r D$ determinant in Enterobacteriaceae isolated from animals, retail meat products, and humans. Microb. Drug Resist. 19, 331-335. doi: 10.1089/mdr.2012.0146

Zhou, K., Yu, W., Shen, P., Lu, H., Wang, B., Rossen, J. W. A., et al. (2017). A novel Tn1696-like composite transposon (Tn6404) harboring bla IMP-4 in a Klebsiella pneumoniae isolate carrying a rare ESBL gene bla SFO-1. Sci. Rep. 7:17321. doi: 10.1038/s41598-017-17641-2

Zioga, A., Whichard, J. M., Kotsakis, S. D., Tzouvelekis, L. S., Tzelepi, E., and Miriagou, V. (2009). CMY-31 and CMY-36 cephalosporinases encoded by ColE1-like plasmids. Antimicrob. Agents Chemother. 53, 1256-1259. doi: 10. 1128/AAC.01284-08

Conflict of Interest: The authors declare that the research was conducted in the absence of any commercial or financial relationships that could be construed as a potential conflict of interest.

Copyright (c) 2019 Ramirez, Iriarte, Reyes-Lamothe, Sherratt and Tolmasky. This is an open-access article distributed under the terms of the Creative Commons Attribution License (CC BY). The use, distribution or reproduction in other forums is permitted, provided the original author(s) and the copyright owner(s) are credited and that the original publication in this journal is cited, in accordance with accepted academic practice. No use, distribution or reproduction is permitted which does not comply with these terms. 